\title{
The Tajno ultramafic-alkaline-carbonatite massif, NE Poland: a review. Geophysics, petrology, geochronology and isotopic signature
}

\author{
Janina WISZNIEWSKA ${ }^{1, *}$, Zdzisław PETECKI ${ }^{1}$, Ewa KRZEMIŃSKA ${ }^{1}$, \\ Anna GRABARCZYK ${ }^{2}$ and Daniel DEMAIFFE ${ }^{3}$
}

1 Polish Geological Institute - National Research Institute, Rakowiecka 4, 00-975 Warszawa, Poland

2 University of Warsaw, Faculty of Geology, Żwirki i Wigury 93, 02-089 Warszawa, Poland

3 Université Libre de Bruxelles (ULB), Département Géosciences, Environnement et Société (CP 160/02), Av. F. Roosevelt, 50 B-1050 Bruxelles, Belgium

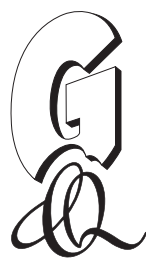

Wiszniewska, J., Petecki, Z., Krzemińska, E., Grabarczyk, A., Demaiffe, D., 2020. The Tajno ultramafic-alkaline-carbonatite massif, NE Poland: a review. Geophysics, petrology, geochronology and isotopic signature. Geological Quarterly, 64 (2): 402-421, doi: 10.7306/gq.1535

Associate Editor: Stanisław Wołkowicz

This paper reviews all available geological data on the Tajno Massif that intruded the Paleoproterozoic crystalline basement of NE Poland (Mazowsze Domain) north of the Teisseyre-Tornquist Zone, on the East European Craton. This massif (and the nearby Ełk and Pisz intrusions) occurs beneath a thick Mesozoic-Cenozoic sedimentary cover. It has first been recognized by geophysical (magnetic and gravity) investigations, then by drilling (12 boreholes down to $1800 \mathrm{~m}$ ). The main rock types identified (clinopyroxenites, syenites, carbonatites cut by later multiphase volcanic/subvolcanic dykes) allow characterizing this massif as a differentiated ultramafic, alkaline and carbonatite complex, quite comparable to the numerous massifs of the Late Devonian Kola Province of NW Russia. Recent geochronological data (U-Pb on zircon from an albitite and Re-Os on pyrrhotite from a carbonatite) indicate that the massif was emplaced at $\sim 348$ Ma (Early Carboniferous). All the rocks, but more specifically the carbonatites, are enriched in $\mathrm{Sr}$, Ba and LREE, like many carbonatites worldwide, but depleted in high field strength elements ( $\mathrm{Ti}, \mathrm{Nb}, \mathrm{Ta}, \mathrm{Zr})$. The initial ${ }^{87} \mathrm{Sr}^{186} \mathrm{Sr}(0.70370$ to 0.70380$)$ and $\varepsilon \mathrm{Nd}(\mathrm{t})(+3.3$ to +0.7$)$ isotopic compositions of carbonatites plot in the depleted quadrant of the Nd-Sr diagram, close to the "FOcal ZOne" deep mantle domain. The $\mathrm{Pb}$ isotopic data $\left({ }^{206} \mathrm{~Pb} /{ }^{204} \mathrm{~Pb}<18.50\right.$ ) do not point to an $\mathrm{HIMU}$ (high U/Pb) source. The ranges of $\mathrm{C}$ and $\mathrm{O}$ stable isotopic compositions of the carbonatites are quite large; some data plot in (or close to) the "Primary lgneous Carbonatite" box, while others extend to much higher, typically crustal $\delta^{18} \mathrm{O}$ and $\delta^{13} \mathrm{C}$ values.

Key words: Tajno intrusion, East European Craton, ultramafic-alkaline-carbonatitic complex, Carboniferous.

\section{INTRODUCTION}

Carbonatite rocks are the most important source of REEbearing deposits on Earth. These deposits occur in neck-like or irregular veins usually composed of various carbonates (mainly calcite; subsidiary dolomite and/or ankerite), with REE-bearing minerals: bastnäsite, parisite, burbankite and monazite (Mariano, 1989; Woolley and Kempe, 1989; Notholt et al., 1990). Carbonatites are commonly associated with polyphase alkaline intrusions characterized by a large variety of rock types: plutonic (clinopyroxenites, various types of syenites and nepheline syenites) and/or alkaline volcanics (nephelinites, trachytes, phonolites) and lamprophyres.

\footnotetext{
* Corresponding author, e-mail: janina.wiszniewska@pgi.gov.pl Received: September 24, 2019; accepted: December 17, 2019; first published online: May 29, 2020
}

Carbonatites and their associated alkaline rocks are emplaced mainly in rift zones in continental cratonic blocks (Woolley, 1989). Few carbonatite occurrences have been reported from the oceanic environments. On the East European Craton (EEC), in the Fennoscandian crustal segment, carbonatites are known in the famous Kola Alkaline Province (KAP) of Late Devonian age (380-360 Ma), which consists of $>20$ intrusions, including the Khibina (also known as Khibiny) and Lovozero agpaitic nepheline syenite massifs (Kogarko et al., 1995; see Downes et al., 2005, for a detailed review). These intrusions, called UAC (ultramafic-alkaline-carbonatite) complexes, are characterized by a rock trilogy: ultramafic cumulates (mainly clinopyroxenites with subordinate peridotites), alkaline silicate rocks (nepheline syenites and/or rocks of the ijolite series) and carbonatites (with associated phoscorites). Some of these intrusions host mineral deposits of economic importance (e.g., apatite, magnetite, pyrochlore, loparite, perovskite, monazite), which are sources of rare metals (Nb, Ta, REE, Zr, Hf) (Woolley, 1989; Wall and Zaitsev, 2004). 
The Late Proterozoic crystalline basement of NE Poland (NE of the Teisseyre-Tornquist Zone) belongs to the EEC (Narkiewicz and Petecki, 2019). It is covered by a thick (several hundred metres) Phanerozoic sedimentary pile.

Prominent intrusive bodies in this crystalline basement were discovered in the late 1950s using regional magnetic and gravity surveys. Several geophysical anomalies were identified within the crystalline basement. They have been explored by numerous drillings, which allow recognizing at least three younger undeformed alkaline plutonic bodies:

1 - relatively small $\left(\sim 12 \mathrm{~km}^{2}\right)$ Tajno clinopyroxenite-carbonatite complex,

2 - much bigger $\left(\sim 400 \mathrm{~km}^{2}\right)$ Ełk alkaline-nepheline syenite intrusion,

3 - Pisz gabbro-syenite intrusion $\left(\sim 170 \mathrm{~km}^{2}\right)$.

Twelve vertical boreholes, to the maximum depth of $\sim 1800 \mathrm{~m}$, were drilled to sample the Tajno complex, which allows conducting various petrological and geochemical investigations. The first geochronological age estimates were obtained using a simple version of the K-Ar method (Depciuch et al., 1975). They yielded rather imprecise Paleozoic ages in the range of 318-285 Ma. A preliminary study of the trace element and REE distribution in carbonatites and pyroxenites was published by Ryka et al. (1992). Many further researches pointed to the possible relationship of the Tajno Massif with the Devonian alkaline intrusions of the Kola Province (Dziedzic, 1973; Krystkiewicz and Krzemiński, 1992; Kubicki, 1992; Ryka, 1992). The first attempt to directly compare the Tajno complex with the Kola Alkaline Province was made in the framework of Polish-Belgian scientific bilateral cooperation between the Polish Geological Institute - National Research Institute and the Département des Sciences de la Terre, Université Libre in Bruxelles (see Demaiffe et al., 2005, 2013, for the discussion of the first results).

This paper is a continuation of our fruitful cooperation and reports new data on geophysics, major and trace elements geochemistry, and bulk rock isotope geochemistry (radiogenic $\mathrm{Sr}, \mathrm{Nd}$ and $\mathrm{Pb}$ isotopes) for the main rock types and stable $\mathrm{C}$ and $\mathrm{O}$ isotope compositions of calcites obtained from ion microprobe analyses. The objectives are (1) to characterize the various carbonatite occurrences within the Tajno complex, and (2) to discuss their petrogenetic relations with some of the main plutonic rock types (clinopyroxenites and syenites) and to identify the nature of their sources.

\section{GEOLOGICAL SETTING AND PREVIOUS GEOPHYSICAL STUDIES OF THE TAJNO MASSIF}

The Paleozoic sub-platform ultramafic-alkaline and carbonatite Tajno intrusion, located in NE Poland (Fig. 1A), is hidden by $\sim 600 \mathrm{~m}$ thick Meso-Cenozoic sediments (Ryka, 1992). This part of the crystalline basement belongs to the unexposed southernmost margin of Fennoscandia. The Tajno igneous body intruded older crystalline rocks of the Mazowsze Domain (Krzemińska et al., 2017), that is a part of a larger orogenic belt of 1.85-1.80 Ga known as Polish-Lithuanian Terrane (Bogdanova et al., 2006). In the Mazowsze Domain, there are various granitoids and volcanics with a geochemically well-documented island arc tectonic setting, formed at 1.84-1.80 Ga (Krzemińska et al., 2005); they are accompanied with greywacke-type sediments deposited during the last phase of the Svecofennian Orogeny (Williams et al., 2009). The early geological description emphasizes the presence of a Jotnian molasse-type deposit forming the Biebrza complex that filled a tectonic graben in the eastern part of the area (Kubicki, 1992). The mature quartz-rich sediments, however, are part of verylate to post-Svecofennian deposits metamorphosed at $1.81 \mathrm{Ga}$ (Krzemiński et al., 2019). Apart from a zone of faults (or a tectonic graben) near the Tajno intrusion (Kubicki, 1992), the crustal discontinuities are manifested by a dyke swarm (consisting mainly of lamprophyre) which extends up to the north to Bargłów IG 2 borehole, $8 \mathrm{~km}$ north of the Tajno Massif. These alkaline lamprophyres of camptonite affinity composition were intruded into the Paleoproterozoic orthogneiss basement at 301.4 to $278.9 \pm 10.6 \mathrm{Ma}$ (K-Ar cooling ages; Krzemiński et al., 2010).

The Tajno complex is located also in the vicinity of a prominent regional magmatic belt - the Mesoproterozoic Mazury Complex - which is a typical anorthosite-charnockite-mangerite-granite association. This AMCG suite trends from NE Poland into Lithuania and Belarus (Wiszniewska et al., 2002), evidencing major lithospheric discontinuities (Skridlaite et al., 2003). After consolidation, the Paleoproterozoic Mazowsze Domain was crosscut by several anorogenic within-plate intrusions emplaced along E-W-trending lineaments between 1.53 and $1.49 \mathrm{Ga}$ (Wiszniewska, 2002; Wiszniewska et al., 2002).

The alkaline intrusions identified by the geophysical methods were intensely explored by drilling: the Pisz body is essentially composed of gabbros and syenites, the Ełk body by foid-bearing syenites, and the Tajno body by clinopyroxenites and syenites, associated with carbonatites (Fig. 1B).

Magnetic and gravity anomaly maps of NE Poland (Fig. 2) reflect the main structural and tectonic features of the Precambrian basement and reveal its complex pattern. Clearly identified geological structures were interpreted as magmatic intrusions (Królikowski and Petecki, 1995; Królikowski et al., 1998; Petecki and Rosowiecka, 2017). Potential field anomaly analysis is then a powerful tool for investigating the subsurface structure of the crystalline basement. The interpretation of the magnetic field data is generally more effective when the crystalline basement is overlain by a thick sedimentary cover because the magnetization contrast between sedimentary and basement rocks is usually high (Clark, 1997). Therefore, the main sources of the magnetic anomalies are expected to depend on the basement setting and its magnetic properties.

The Tajno gravity and magnetic anomalies, covering an area of $\sim 12 \mathrm{~km}^{2}$, have been discovered for the first time during a regional gravity survey, and subsequent semi-detailed gravity and magnetic surveys conducted in the years 1952-1964 (Cieśla and Kosobudzka, 1992). These high-amplitude positive anomalies are clearly marked in the low-amplitude regional magnetic and gravity patterns of northeastern Poland (Fig. 2). They are both characterized by a nearly circular shape and show a good correlation between each other. The data collected during the semi-detailed studies have been used to determine the location of the first borehole (marked as Tajno IG 1) drilled in 1965. Ultramafic rocks were recorded at the depth interval of $600-1200 \mathrm{~m}$, below the Meso-Cenozoic cover. Due to the interesting results of this first borehole, four other boreholes were drilled in 1965-1966 (Tajno IG 2, IG 3, IG 5 and IG 6). Preliminary petrographic data obtained from these boreholes have clearly indicated the relationship between the geophysical anomalies and the alkaline ultramafic rocks (Kubicki, 1992). Large magnetic susceptibility and density contrasts between the alkaline rocks of the Tajno Massif and surrounding rocks of the basement have further been established by laboratory measurements of the physical properties of studied rocks. 


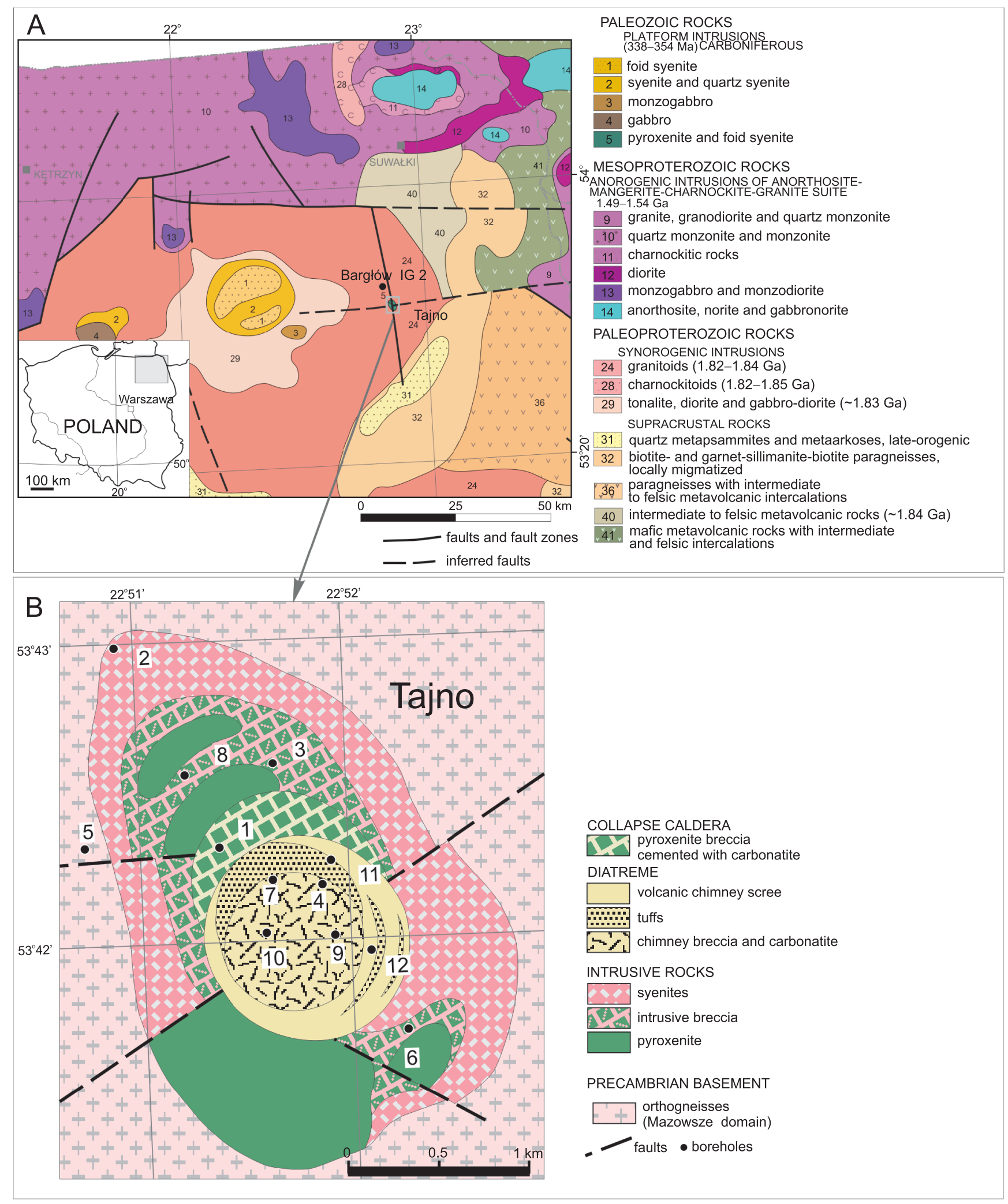

Fig. 1A - geological map of the crystalline basement of NE Poland after Krzemińska et al. (2017) showing location of the Tajno area (box); B - geological map of the Tajno Massif at $500 \mathrm{~m}$ b.s.l. after (Ryka, 1992), modified, showing location of the deep boreholes 
A

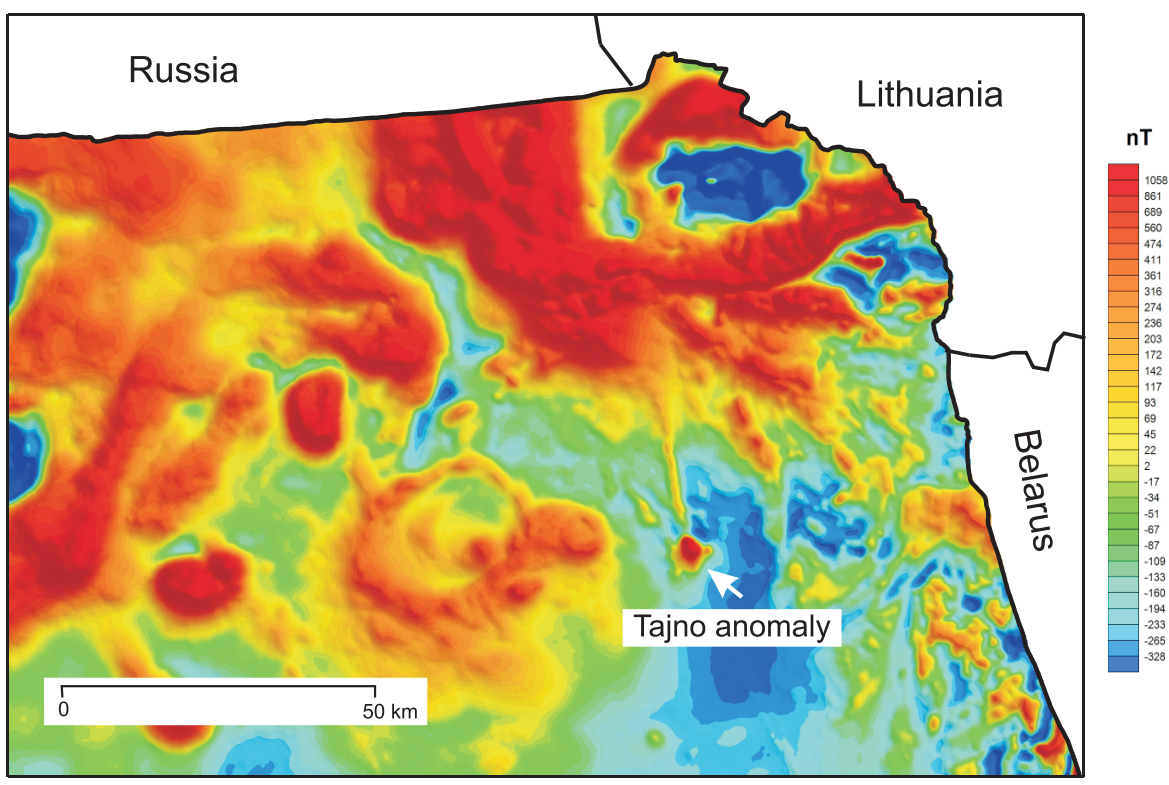

$\mathrm{B}$

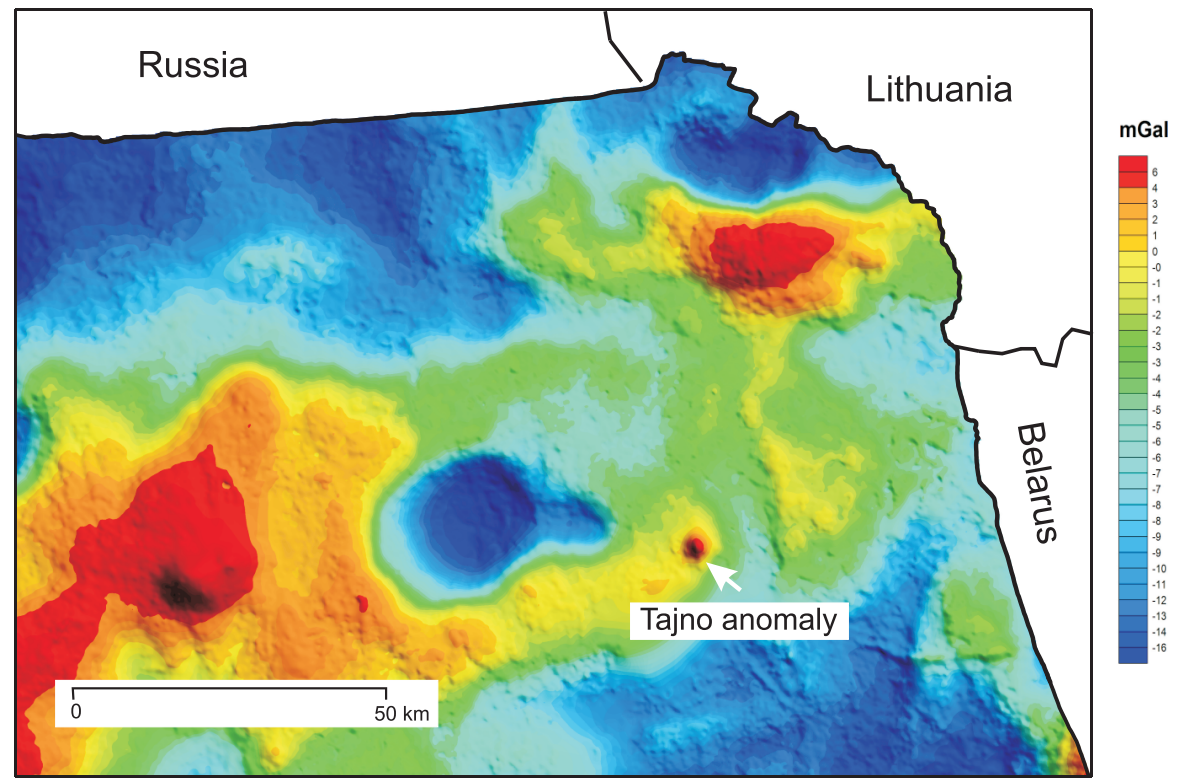

Fig. 2. Geophysical characteristics of the basement in NE Poland

A - total intensity magnetic anomaly map (in nanoTesla: $\mathrm{nT}$ ); B - Bouguer gravity anomaly map (in milliGals: mGal)

\section{MATERIALS AND ANALYTICAL METHODS}

\section{GEOPHYSICAL METHODS}

Very detailed magnetic and gravity studies were carried out over the central part of the anomaly with a grid density of $0.15 \mathrm{~km}$ and outside the centre, on a basis of regular $0.3 \mathrm{~km}$ grid. The magnetic and gravity measurements collected during the detailed studies were merged with previous semi-detailed measurements. However, the southern edge of the anomaly is insufficiently recognized due to the presence of Tajno Lake and swamps (Cieśla and Kosobudzka, 1992). The data have been processed in order to better visualize structural features of the Tajno structure.

Interpretation of the geophysical data has been performed using several methods of magnetic and gravity field transformations. It appears that the location of the first five boreholes drilled in 1965-1966 was not favourable with respect to the local magnetic and gravity anomalies of the Tajno area (Cieśla and Kosobudzka, 1992). 
To enhance the geophysical contrasts, which is critical for the definition of the structural framework at the source of the Tajno anomaly, data processing in this study was focused on the enhancement of the short wavelength features, which is more suitable for high-resolution mapping of crystalline basement. Magnetic data processing consisted of reduction to the pole and analytical downward continuation to a depth of $600 \mathrm{~m}$. The resulting map was then low-pass filtered. The reduction-to-the-pole method transforms the observed magnetic anomalies into the anomalies that would have been measured if both the magnetization and ambient field were vertical to bring anomalies directly over their geological sources (Blakely, 1995). This method requires knowledge of the direction of magnetization, assumed to be parallel to the ambient field, as would be the case if remanent magnetization is either negligible or aligned parallel to the ambient field. Downward continuation transforms the potential field measured on one surface to the field that would be measured on another surface nearer to sources to enhance details of the source distribution. As this transformation greatly amplified the shortest wavelength anomalies (Blakely, 1995) the low-pass Butterworth filter with cut-off wavelengths equal $1000 \mathrm{~m}$ was used to remove spurious high wavelengths.

\section{GEOCHEMICAL METHODS}

Twenty-five samples were analysed for major element geochemistry using XRF methods, and trace elements were measured by FI ICP-mass spectrometry using a one-point "linear through zero" calibration. The measurements were made on a Sciex Perkin Elmer ELAN 5000a ICP-MS machine. A detailed description of the procedure for the trace element measurements at CRPG, CNRS (Nancy, France) can be found in Carignan et al. (2001). Geochemical results of the 25 samples are presented in Appendix $1^{*}$.

\section{U-Pb ZIRCON METHOD}

Six zircon grains with concentric zoning were analysed at the Centre de Recherches Pétrographiques et Géochimiques (CRPG, CNRS; Nancy, France).

The zircon grains separated from the Bargłów IG 2 and Tajno IG 5 country rock orthogneisses were analysed for U-Th- $\mathrm{Pb}$ age determinations using the SHRIMP // I/e/MC ion microprobe at the Research School of Earth Sciences of Australian National University (Canberra). During the analytical session the zircon standards FC1 (radiogenic ${ }^{206} \mathrm{~Pb} /{ }^{238} \mathrm{U}=0.1859$ ) and SL13 $(U=238 \mathrm{ppm})$ and techniques based on those of Williams and Claesson (1987) were applied. The analytical results (Appendix 2) were calculated and plotted using Isoplot 3 (Ludwig, 2003) geochronological toolkits for Microsoft Excel.

\section{Re-Os (ID-NTIMS) METHOD}

To obtain a Re-Os age, sulphide analyses from Tajno carbonatites were done by isotope dilution-negative thermal ion mass spectrometry (ID-NTIMS) at the Applied Isotope Research for Industry and Environment (AIRIE Program, Colorado State University, Fort Collins, USA).

\section{Rb-Sr AND Sm-Nd METHODS}

The analytical procedure for the $\mathrm{Rb}-\mathrm{Sr}$ and $\mathrm{Sm}-\mathrm{Nd}$ methods can be found in Ashwal et al. (2002).

Samples for $\mathrm{Rb}-\mathrm{Sr}$ and $\mathrm{Sm}-\mathrm{Nd}$ isotopic analyses were dissolved in a mixed $\mathrm{HF}-\mathrm{HNO}_{3}(10: 1)$ solution. Chemical separation of $\mathrm{Rb}, \mathrm{Sr}, \mathrm{Sm}$ and $\mathrm{Nd}$ was carried out by cation-exchange chromatography; procedural blanks were $<1 \mathrm{ng}$. $\mathrm{Sr}$ and $\mathrm{Nd}$ isotopic ratios were measured on a VG Sector 54 multicollector thermal ionization mass spectrometer housed at the Université Libre de Bruxelles, Belgium. Replicate analyses of the MERCK $\mathrm{Nd}$ standard gave an average ${ }^{143} \mathrm{Nd} /{ }^{144} \mathrm{Nd}$ value of $0.512742 \pm 8$ (normalized to ${ }^{146} \mathrm{Nd} /{ }^{144} \mathrm{Nd}=0.7219$ ), and measurements of NBS $987 \mathrm{Sr}$ standard yielded an average ${ }^{87} \mathrm{Sr} /{ }^{86} \mathrm{Sr}$ value of $0.710247 \pm 7$ (normalized to ${ }^{86} \mathrm{Sr} /{ }^{88} \mathrm{Sr}=0.1194$ ). On the basis of routine laboratory replicate analyses, ${ }^{147} \mathrm{Sm} /{ }^{144} \mathrm{Nd}$ and ${ }^{87} \mathrm{Rb} /{ }^{86} \mathrm{Sr}$ ratios are reproducible to better than 0.2 and $0.5 \%$, respectively. $\mathrm{Rb}-\mathrm{Sr}$ and $\mathrm{Sm}-\mathrm{Nd}$ isotopic data are given in Appendix 3. Epsilon $\mathrm{Nd}$ values were calculated assuming ${ }^{147} \mathrm{Sm} /{ }^{144} \mathrm{Nd}=$ 0.1967 and ${ }^{143} \mathrm{Nd} /{ }^{144} \mathrm{Nd}=0.512638$ for Chondritic Uniform Reservoir (CHUR).

\section{STABLE ISOTOPE METHODOLOGY}

Carbon and oxygen isotope compositions of calcites selected from the Tajno IG 4 chimney breccia were measured at the Polish Geological Institute - National Research Institute using the Secondary lon Mass Spectrometry (SIMS) technique on SHRIMP IIe/MC. Single calcite grains were embedded in a 2.5 $\mathrm{cm}$ diameter epoxy mount together with the NBS-18 calcite reference material. The measured isotope ratios are expressed as $\delta^{13} \mathrm{C}$ and $\delta^{18} \mathrm{O}$ relative to VPDB (Vienna Pee Dee Belemnite) and VSMOW (Vienna Standard Mean Ocean Water), respectively. Results were expressed in per mil using the conventional $\delta$-notation. The reference values of NBS-18 and the summary of results are listed in Table 1. The detailed single spot $\delta^{13} \mathrm{C}$ and $\delta^{18} \mathrm{O}$ isotope ratios are presented in Appendix 4.

\section{GEOPHYSICAL IMAGING}

The Tajno magnetic and gravity anomalies obtained on the basis of detailed geophysical measurements supplemented by semi-detailed data are shown in Figure 3A, B, respectively. The Tajno magnetic anomaly has a nearly circular shape and high amplitude of $\sim 1600 \mathrm{nT}$. It is bordered by narrow high gradient zones (Fig. $3 \mathrm{C}$ ). The gravity anomaly has an amplitude of $\sim 0.06 \mathrm{~m} / \mathrm{s}^{2}(6 \mathrm{mGal})$. It corresponds to the shape of the magnetic anomaly (Fig. 3D) suggesting that both anomalies (gravimetric and magnetic) are caused by the same igneous body with intense magnetic susceptibility and density contrasts between the intrusive rocks and their host basement.

The transformed magnetic and gravimetric maps (Fig. 3C, D) show the composite character of the Tajno anomalies. The pattern of maxima and minima and gradient zones in the anomalies provides the outline of the Tajno magmatic body, indicating significant lithological diversity of the source body.

The anomaly fields are composed by a series of isolated high/low magnetic anomalies, which can be grouped in two do- 
The stable isotope $(\mathrm{O}, \mathrm{C})$ data for calcite separates from the Tajno IG 4 sample, depth $570 \mathrm{~m}$

\begin{tabular}{|c|c|c|c|c|c|c|c|c|c|}
\hline Sample & $\begin{array}{c}\text { Min } \\
\delta^{13} \mathrm{C}[\% 0]\end{array}$ & $\pm[\% 0]$ & $\begin{array}{c}\text { Max } \\
\delta^{13} \mathrm{C}[\% 0]\end{array}$ & $\pm[\% \circ]$ & $\begin{array}{c}\text { Min } \\
\delta^{18} \mathrm{O}[\% 0]\end{array}$ & $\pm[\%$ o $]$ & $\begin{array}{c}\text { Max } \\
\delta^{18} \mathrm{O}[\% 0]\end{array}$ & $\stackrel{ \pm}{ \pm}$ & $\mathrm{n}$ \\
\hline PIC * & -7.7 & & -3.1 & & 5.3 & & 8.4 & & \\
\hline $\begin{array}{l}\text { Tajno IG } 4 \\
\text { (Ryka, 1992) }\end{array}$ & -5.91 & - & +1.31 & - & 7.66 & & 13.86 & & \\
\hline $\begin{array}{l}\text { Tajno IG } 4 \\
\text { SHRIMP data } \\
\text { (this study) }\end{array}$ & -9.33 & 0.44 & 6.49 & 0.48 & 5.86 & 0.11 & 24.39 & 0.12 & 79 \\
\hline $\begin{array}{l}\text { Tajno IG } 4 \text { SHRIMP } \\
\text { averages** }\end{array}$ & & & -2.2 & 1 & & & 13.5 & 1 & 79 \\
\hline $\begin{array}{l}\text { NBS18 } \\
\text { SHRIMP analysed }\end{array}$ & -5.06 & 0.78 & & & $\begin{array}{l}-23.2 \text { (VPDB) } \\
+7.14 \text { (VSMOW) }\end{array}$ & $\begin{array}{l}0.22 \\
0.25\end{array}$ & 24.39 & 0.12 & 66 \\
\hline $\begin{array}{l}\text { NBS18 standard } \\
\text { reference values }\end{array}$ & -5.014 & 0.04 & & & -23.2 (VPDB) & 0.12 & $\begin{array}{c}+7.20 \\
\text { (VSMOW) }\end{array}$ & 0.1 & \\
\hline
\end{tabular}

* - PIC - Primary Igneous Carbonatites (Taylor et al., 1967); ** - single grain calcites analysed by SHRIMP

mains with characteristic amplitudes and wavelengths. Downward continuation of the reduced-to-the-pole magnetic anomaly (Fig. 3C) showed that two magnetic domains can be distinguished. The first one is located in the central part of the massif and corresponds to a circular magnetic low. The gravity low is also marked in the transformed gravity field in that area (Fig. 3D); The second one is larger and surrounds the central domain. It is characterized by large amplitude magnetic and gravity anomalies (Fig. 3C, D). At its western limit, it has large magnetic and gravity highs with two isolated anomalies of large amplitudes.

The interpretation of transformed geophysical maps suggests that the Tajno Massif is a complex geological structure characterized by the presence of several distinct contrasts in physical properties of rocks implying large petrophysical diversity. Rocks with high density and strong magnetic properties, related mainly to the presence of clinopyroxenites (Kubicki, 1992), are dominant especially in the western part of the massif. Remarkable features on the magnetic and gravity anomaly maps are the lows especially strongly manifested in the magnetic field (Fig. 3C), while in the gravity field they are much weaker (Fig. 3D). These anomaly lows cover a circular area of $\sim 0.75 \mathrm{~km}$ in diameter and are related to the crater-facies rocks (Kubicki, 1992) with weaker magnetic properties and lower density.

The first five boreholes (Tajno IG 1, IG 2, IG 3, IG 5 and IG 6 ) were drilled at the periphery of the positive anomalous zone (Fig. 3), out of the range of the interesting strongest anomalies. Therefore, these boreholes do not allow explaining the origin and source of local magnetic and gravimetric lows, but they revealed the presence of ultramafites, hybrid rocks and syenites. The Tajno IG 5 borehole penetrated their host metamorphic, orthogneissic basement.

To try to understand the origin of geophysical anomalies and their petrographic nature, five additional boreholes (Tajno IG 4, IG 7, IG 9, IG 11 and IG 12) were drilled in the years 1984-1987 (Figs. 3C, D and 4) within the local magnetic low (Fig. 3C). They have penetrated a palaeovolcanic crater filled with explosive breccia and pyroclastic material cut by mafic dykes and carbonatite veins containing REE minerals (Kubicki, 1992). The Tajno IG 4 borehole, located in the central part of this negative magnetic anomaly, revealed the presence of chimney breccia (chimney-like mass of brecciated rock cemented with later fine-grained matrix) composed mainly of clinopyroxenite, trachyte and phonolite crosscut by calciocarbonatite veins or veinlets and, in some places, by foid syenite and monzogabbro/monzodiorite (Fig. 4). The Tajno IG 7 borehole is located also in the central part of the chimney, NW from the Tajno IG 4. It contains mainly pyroclastic material, tuff and volcanic debris from 880 to $1250 \mathrm{~m}$ interval. Volcanic rocks (trachyte and phonolite) are present within the volcanic pipe (formed by the rapid eruption of deep-seated source filled with solidified magma, volcanic breccia, and fragments of older rock). The rocks in the Tajno IG 9 borehole are similar in composition to those in Tajno IG 7. Apart from pyroclastic breccia, layers of essexite (foid monzogabbro/monzodiorite) and clinopyroxenite have been encountered. Intrusive breccia of pyroxenite-foid syenite composition and hybridic (fenitized?) pyroxenites, essexites and clinopyroxenites were found in the Tajno IG 10 borehole. In the Tajno IG 11, the section is composed of chimney breccia with clinopyroxenite cut by trachyte and phonolite (Fig. 4). Calciocarbonatite veins and veinlets with fluorite mineralization crosscut the eruptive-explosive chimney breccia material in most of studied boreholes. The rocks of the crater facies are characterized by much weaker magnetic properties than those surrounding the massif (Cieśla and Kosobudzka, 1992).

\section{PETROGRAPHIC OVERVIEW AND SAMPLING}

Petrographic descriptions and preliminary interpretation of the Tajno rocks are given in several contributions (Juskowiak, 1973; Ryka, 1992; Krystkiewicz and Krzemiński, 1992; Demaiffe et al., 2005; Brassinnes at al., 2005; Kozłowski et al., 2005; Krzemiński et al., 2010). The Tajno complex is composed mainly of clinopyroxenites (Fig. 1B) surrounded by syenites with a central ( $800 \mathrm{~m}$ in diameter) volcanic pipe that contains numerous crushed fragments of alkaline volcanic rocks (e.g., trachytes, phonolites, foidites) crosscut and cemented by carbonatite veins of variable thickness, which host fluorite and sulphide mineralisation. The boreholes sited within the chimney 

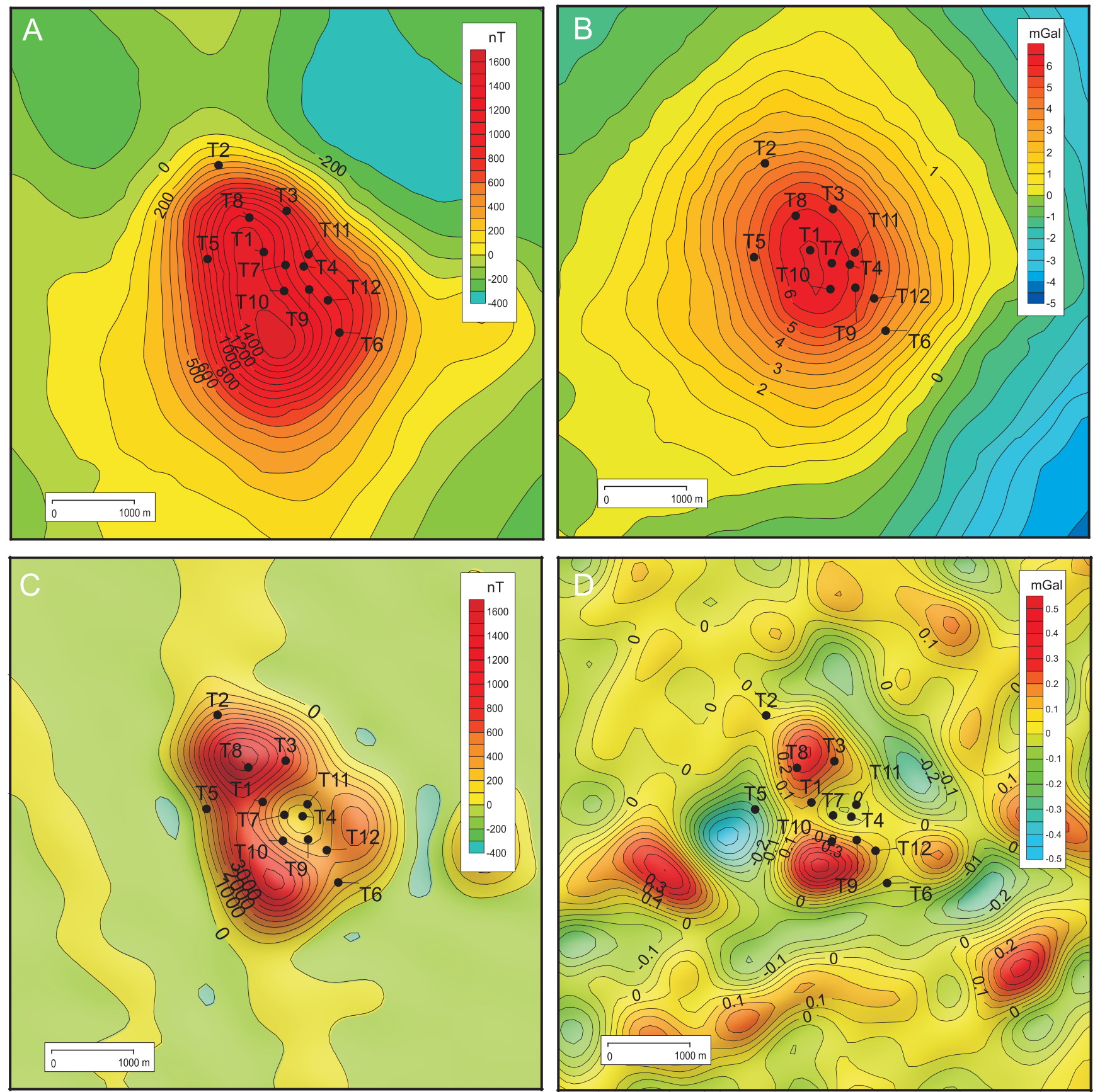

Fig. 3. Geophysical characteristics of the basement of the Tajno area

A - total intensity magnetic anomaly map (in nanoTesla: nT); B - Bouguer gravity anomaly (in milliGals: mGal); C - reduced-to-the-pole, downward-continued and low-pass filtered total intensity magnetic anomaly map (in nanoTesla: nT); $\mathbf{D}$ - band-pass filtered gravity anomaly map (in milliGals: mGal); T1-T12 - location of the Tajno IG 1-Tajno IG 12 boreholes

breccia (Tajno IG 7, IG 9, IG 10, IG 11 and IG 12; Fig. 4) document a palaeovolcanic crater filled with eruptive-explosive breccia material in which most rocks, including pyroclastic material, were brecciated and altered by infiltrating fluids and then cut by mafic dykes and calciocarbonatite veins. This sequence of geological processes has generated complex and/or hybrid rocks, especially during the interaction of previously consolidated rocks with carbonatitic melts/fluids. Some of these hybrid or deeply transformed rocks could be called fenites. As a consequence, rock types observed in boreholes are highly variable
(Figs. 4 and 5). Many attempts have been made in the literature to categorize and name these complex/hybrid rocks (Ryka, 1992; Krystkiewicz and Krzemiński, 1992). The present contribution is nevertheless focused on the general rock nomenclature proposed by the International Union of Geological Sciences (Le Maitre, 2002). Photomicrographs of the main rock types are given in Demaiffe et al. (2005).

Syenites are abundant in the Tajno Massif. They form the outermost parts of the complex. Two end-members can be distinguished (Demaiffe et al., 2005, 2013): 1 - syenites (with minor 
melasyenites) containing early-formed tabular and weakly zoned clinopyroxene (Mg\# in the core: $0.76-0.63$; low $\mathrm{Na}_{2} \mathrm{O}$ content: 0.75-1.22 wt.\%), titanite, and apatite embedded in large poikilitic, perthitic alkali feldspars; and 2 - nepheline syenites with large twinned microperthitic alkali feldspar laths and late-stage, strongly zoned clinopyroxene with colourless augite cores (Mg\#: 0.76 ), dark green aegirine-augite to augite rims ( $\mathrm{Mg \#}$ as low as $0.23 ; \mathrm{Na}_{2} \mathrm{O}$ up to 4.35 wt.\%) and auto- and hypautomorphic nepheline crystals. It is very often replaced by aggregates of fine blades of cancrinite and sporadic sodalite (Krystkiewicz and Krzemiński, 1992). Some syenites contain lamprophyllite, a typical mineral of the agpaitic nepheline syenite of the Lovozero intrusion (Kola Peninsula) (Demaiffe et al., 2005). Typical syenites were sampled from $690.4 \mathrm{~m}$ (the top of the Tajno intrusion) to $814.3 \mathrm{~m}$ depth in Tajno IG 2 borehole and down to $1254.6 \mathrm{~m}$ depth (bottom of the borehole) in Tajno IG 8.

Clinopyroxenites have typical cumulate textures, the main cumulus phases being diopside + magnetite + titanite with subordinate amounts of apatite and, rarely, of olivine. Interstitial phlogopite, amphibole and alkali feldspar fill the intercumulus space (Fig. 6A). Tremolite-biotite aggregates and serpentinite-group minerals sporadically occur as secondary phases. Variations in grain size are common with clinopyroxene of two distinct habits:
- large (>3 mm), zoned, melt inclusions-rich augites (Mg\# of the cores: $0.86-0.75)$ that occur locally as broken clasts embedded in a fine-grained matrix;

- elongate, prismatic, unzoned and inclusion-free augites (Mg\#: 0.78-0.61) (Ryka, 1992; Demaiffe et al., 2005, 2013).

Grain size and deformation texture (cataclasis) differ from sample to sample (Demaiffe et al., 2005, 2013). Representative clinopyroxenites were sampled in Tajno IG 1 (761 m depth), Tajno IG 6 (614.5, 708.2 and $1180.4 \mathrm{~m}$ depth) and Tajno IG 10 (1049.5 m depth).

Carbonatites occur as veins, ranging in thickness from a few $\mathrm{cm}$ up to $50 \mathrm{~cm}$ (Figs. 5A-C and 6B, D). Three carbonatite stages with various REE distributions have been recognized (Gaczyński, 1978; Ryka, 1992; Brassinnes et al., 2005; Wiszniewska and Sikorska, 2005):

- the early stage, represented by calciocarbonatites, has only been found as fragments in the central breccia (Fig. 5A);

- the second stage, which also consists mainly of calcite, represents the main stage and occurs as veins and cement in the chimney breccia; they crosscut the clinopyroxenites and syenites (Fig. 5B, C);

- late-stage carbonatites, composed of ferroan dolomite and ankerite, are related to late hydrothermal activity. The grain size of these carbonatites strongly varies from vein to vein and from one borehole to the other. Most carbonatites are fine-grained, but the calcite crystals can locally be $>10 \mathrm{~mm}$.

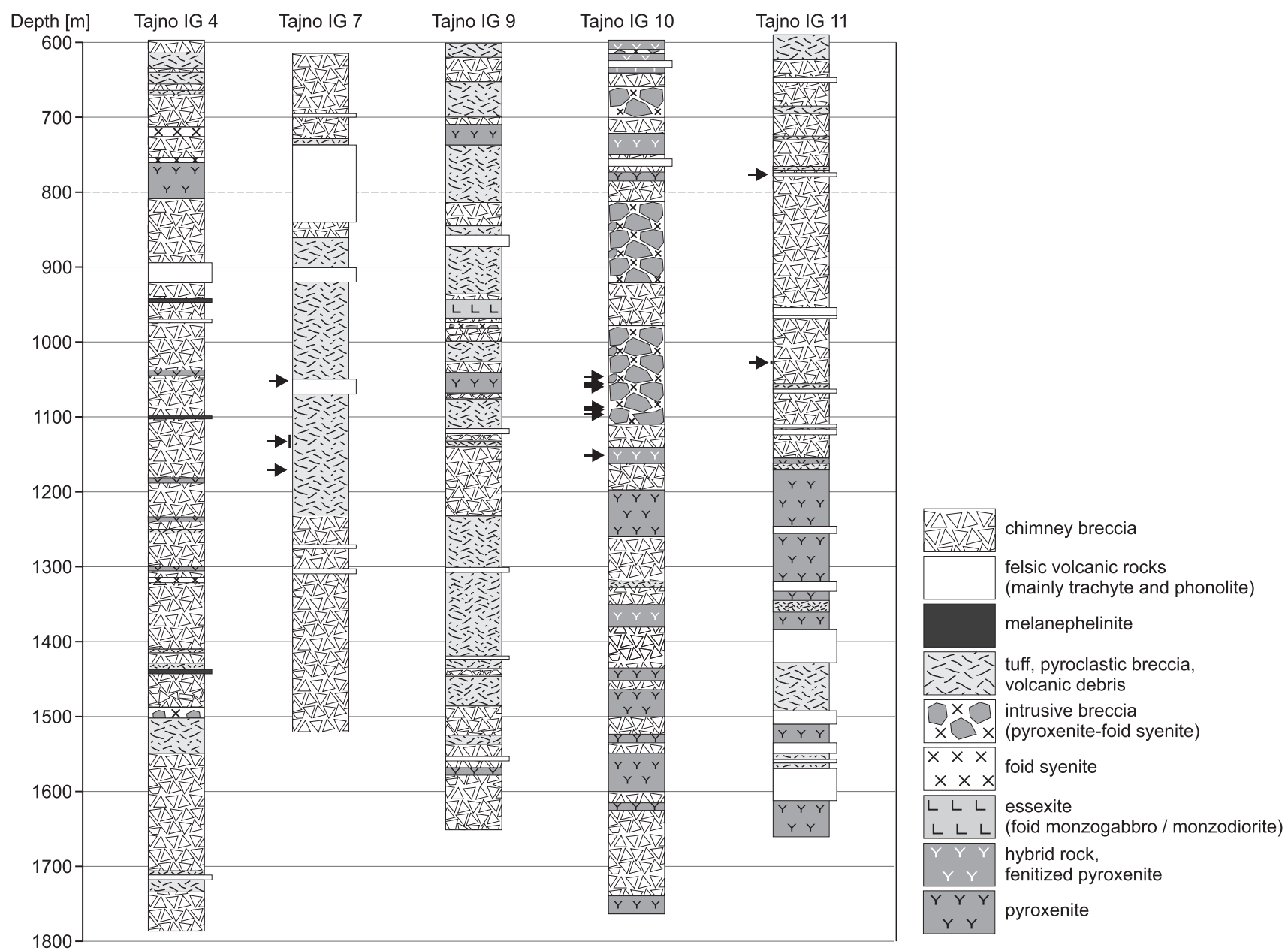

Fig. 4. Selected lithological logs of the Tajno boreholes (L. Krzemiński, unpubl. data, 2019) 
The texture is mainly granular, sometimes porphyroclastic. Comb texture (Fig. 5C) with elongate calcite grains (similar to those observed in the Kaiserstuhl carbonatite veins; Katz and Keller, 1981) has been described by Ryka (1992). Calcite, the main type of carbonate, is usually Sr-rich; it locally contains numerous strontianite inclusions (Fig. 6).

Other carbonates (dolomite, ankerite, burbankite, and REE-bearing fluorocarbonates; with primary and hydrothermal fluorite) have been identified, but are of minor importance. Fluorite occurs as cement in the central breccia (Fig. 5C, D); its modal abundance can be as high as $60 \%$ (Kozłowski et al., 2005). Sulphides, mainly pyrite, pyrrhotite and chalcopyrite, are locally quite abundant; they sometimes occur as large $(15 \mathrm{~mm})$ grains (Fig. 5B-D). Magnetite is locally present. Coarse (up to $10 \mathrm{~mm}$ ), euhedral, twinned alkali feldspar is the main silicate phase; phlogopite and aegirine are subordinate. The typical Nband/or Zr-rich accessory minerals like pyrochlore, perovskite, zirconolite and baddeleyite, which are commonly found in many carbonatites worldwide, are very rare in the Tajno carbonatites (Fig. 6B). Instead, REE-bearing minerals, often F-bearing, such as burbankite, parisite, synchysite and bastnäsite, are widespread in Tajno.

Twelve carbonatite samples have been selected: Tajno IG 7 (1128.6, 1134.0, 1138.0, 1138.5 and $1139.2 \mathrm{~m}$ depth), Tajno IG $10(1059.7,1062.6,1083.0,1085$ and $1151.0 \mathrm{~m}$ depth $)$ and Tajno IG 11 (1026 and $1027.5 \mathrm{~m}$ depth).

Dykes of volcanic or subvolcanic rocks are abundant in the central part of the Tajno intrusion, especially within the chimney breccia (Fig. 5).

Trachytes are common: they contain primary albite phenocrysts and subordinate alkali feldspar in a fine-grained matrix. Subvolcanic dykes crosscut the plutonic series. Krystkiewicz and Krzemiński (1992) identified three groups of rocks: ultrabasic foidites or nephelinites, phonolites-tephrites and tinguaites. Two
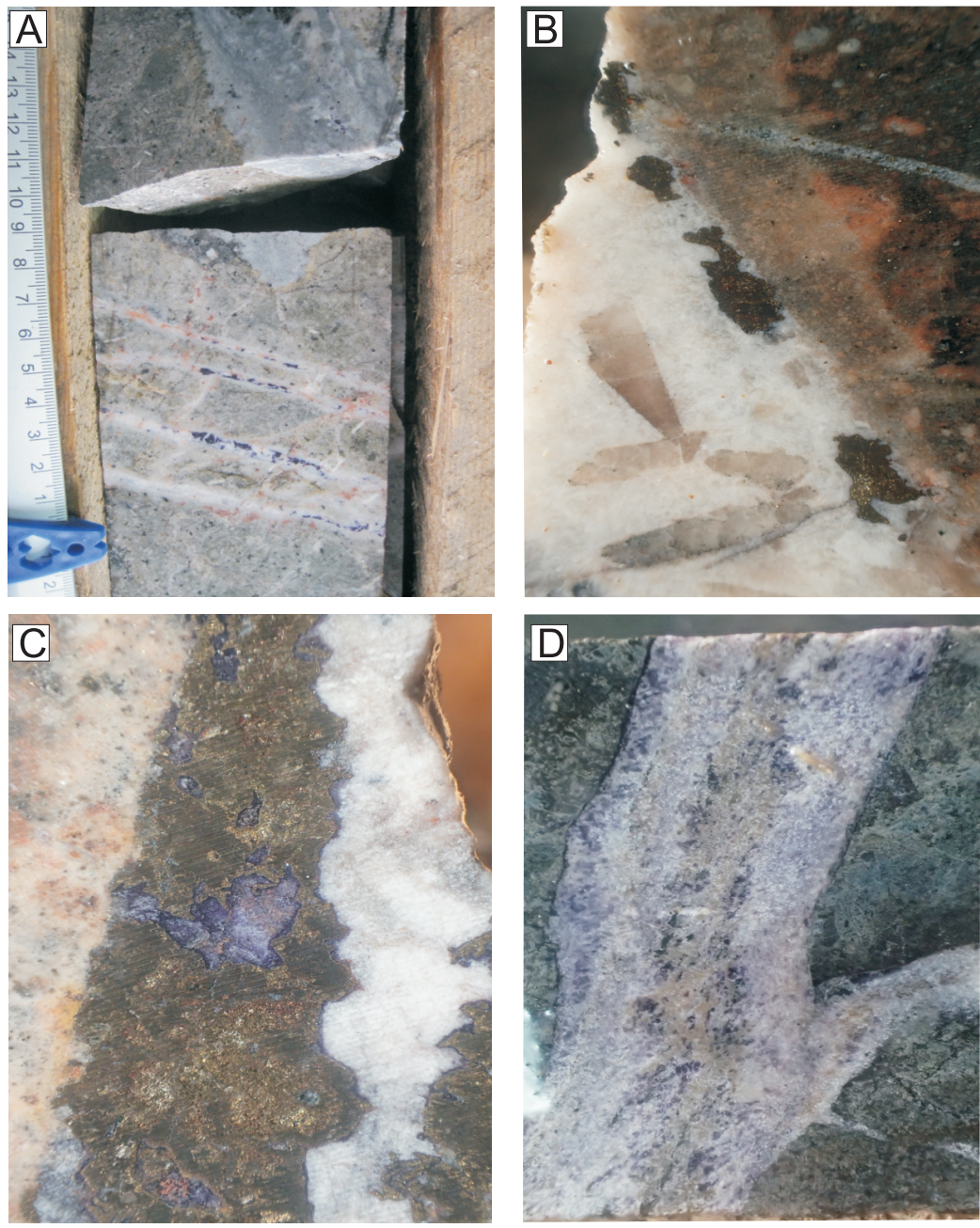

Fig. 5. Selected borehole images from the Tajno intrusion

A - trachyte from the central breccia pipe mixed with carbonatite of the first stage, crosscut by secondary carbonatite veinlets with sulphide grains (Tajno IG 10, depth $1060.2 \mathrm{~m}$ ); B - thick vein of coarse-grained carbonatite with late apatite and sulphide (pyrite, pyrrhotite and chalcopyrite) mineralisation at the contact with a trachyte dyke; the third stage veinlets are visible; Tajno IG 10 (depth 1058-1069 m; C - thick vein of sulphide mineralisation with fluorite replacing a primary carbonatite vein (comb structure), cemented chimney breccia (Tajno IG 11, depth $1298 \mathrm{~m}$ ); D - fluorite-rich carbonatite veins crosscutting clinopyroxenite and trachyte from the chimney breccia (Tajno IG 11, depth $1307.0 \mathrm{~m}$ ); for figures $\mathrm{B}, \mathrm{C}$ and $\mathrm{D}$, the magnification is twice that of $\mathrm{A}$ 
volcanic samples were selected: a tuff from Tajno IG 7 (1050.5 m depth) and a trachyte from Tajno IG 11 (778.6 m depth).

Albitites are composed mainly of anhedral albite grains. Accessory magnetite and apatite have been found, but Fe-Mg silicates are absent. Carbonates occur as small interstitial grains, sometimes aggregated, sometimes as diffuse veinlets. Zircon grains $(50-200 \mu \mathrm{m})$ are closely associated with the carbonate seams. These albitites could result from the thorough metasomatic transformation (albitization) of former syenites or former country rocks induced by the infiltration of carbonatitic melts. Two albitite samples were selected: Tajno IG 1 (769.5 m depth) and Tajno IG 10 (1091 m depth).

\section{GEOCHEMISTRY}

A selection of 25 representative samples of major rock types from the Tajno Massif have been analysed for major and trace elements, including REEs: 13 carbonatites, 5 clinopyro- xenites, 3 syenites, 2 albitites and 2 volcanic rocks (a tuff and a trachyte). They were collected from the six different boreholes: IG 1, IG 2, IG 6, IG 7, IG 10 and IG 11. The analytical results are listed in Appendix 1 as supplementary material.

Preliminary interpretation of the geochemical data obtained on the above-mentioned Tajno samples has been published in an extended abstract of the Suwałki Conference of the Polish Mineralogical Society (Demaiffe et al., 2005). We will briefly summarize some of these data with a special focus on carbonatites.

The abundances of major and trace elements have been plotted on binary diagrams (Fig. 7) versus La content (ppm, logarithmic scale) to illustrate the obvious geochemical differences between the silica-poor carbonatites and the alkaline silicate rocks (syenites and clinopyroxenites). The latter have significantly higher $\mathrm{TiO}_{2}$ content due to the presence of accessory titanite (Fig. 6).

Compared to average carbonatites worldwide, the Tajno carbonatites have very low $\mathrm{Nb}$ content (from 0.5 to $4.7 \mathrm{ppm}$ )
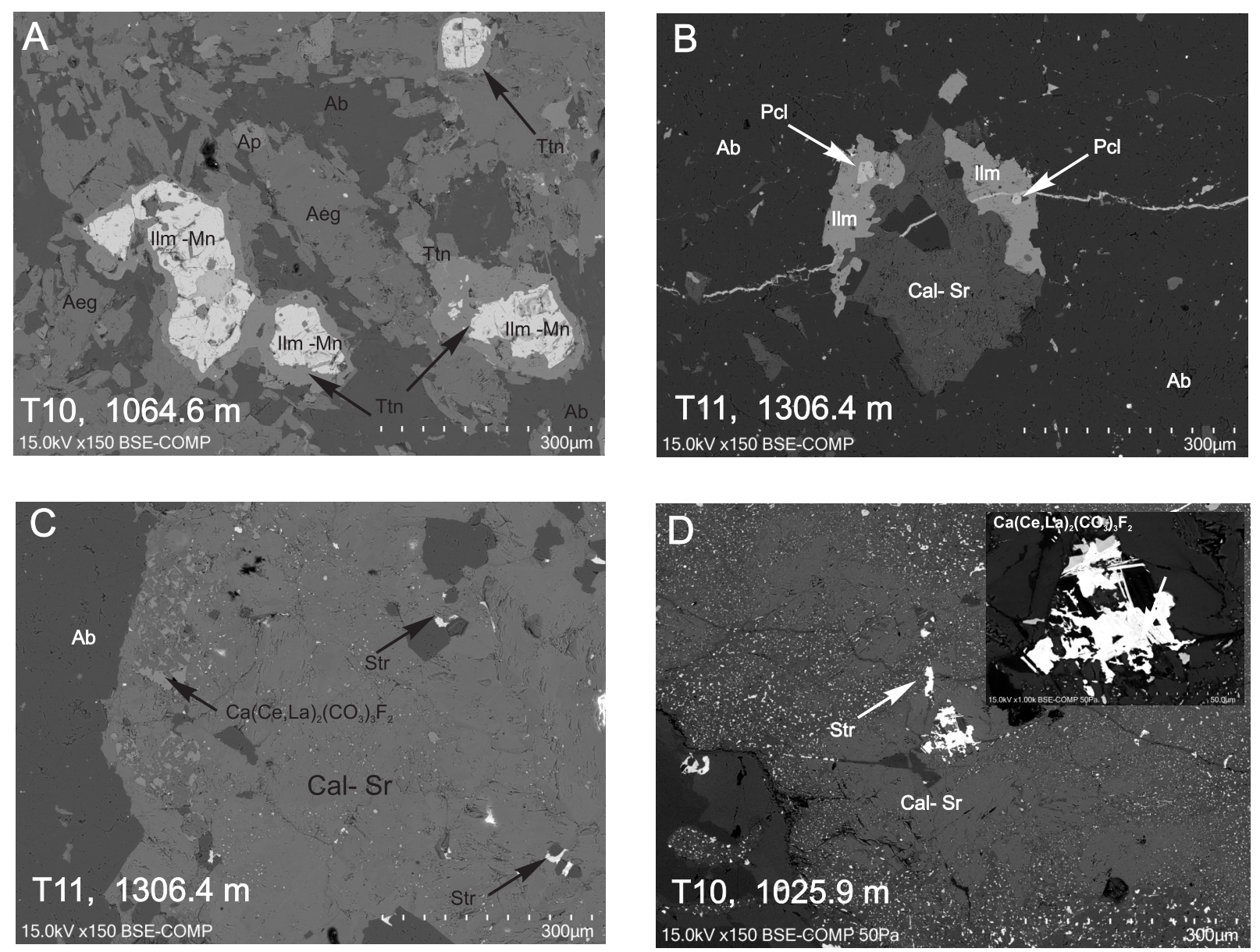

Fig. 6. Back-scattered electron (BSE) images obtained with a HITACHI Su3500 electron microscope, showing representative occurrences of clinopyroxenite and carbonatite and their main mineral assemblages

A - clinopyroxenite (Tajno IG 10, depth $1064.6 \mathrm{~m}$ ) close to carbonatite contact. Typical mafic aggregate of aegirine-augite and $\mathrm{Mn}$-rich ilmenite with sporadic euhedral titanite and apatite. Note a titanite corona on ilmenite. B - carbonatite with Sr-rich calcite and ilmenite, including a very rare pyrochlore grain (Tajno IG 11, depth $1306.4 \mathrm{~m}$ ). C - same carbonatite with Sr-rich calcite that hosts strontianite and REE carbonate-fluoride minerals. D - carbonatite (Tajno IG 10, depth 1025.9m) with Sr-rich calcite containing dispersed strontianite and REE carbonate-fluoride inclusions; Ab - albite, Aeg - aegirine, Ap - Apatite, Cal-Sr - Sr-bearing calcite, IIm - ilmenite, IIm-Mn - Mn-bearing ilmenite; Pcl - pyrochlore, Str - strontianite, Ttn - titanite; all figures are presented at the same magnification 

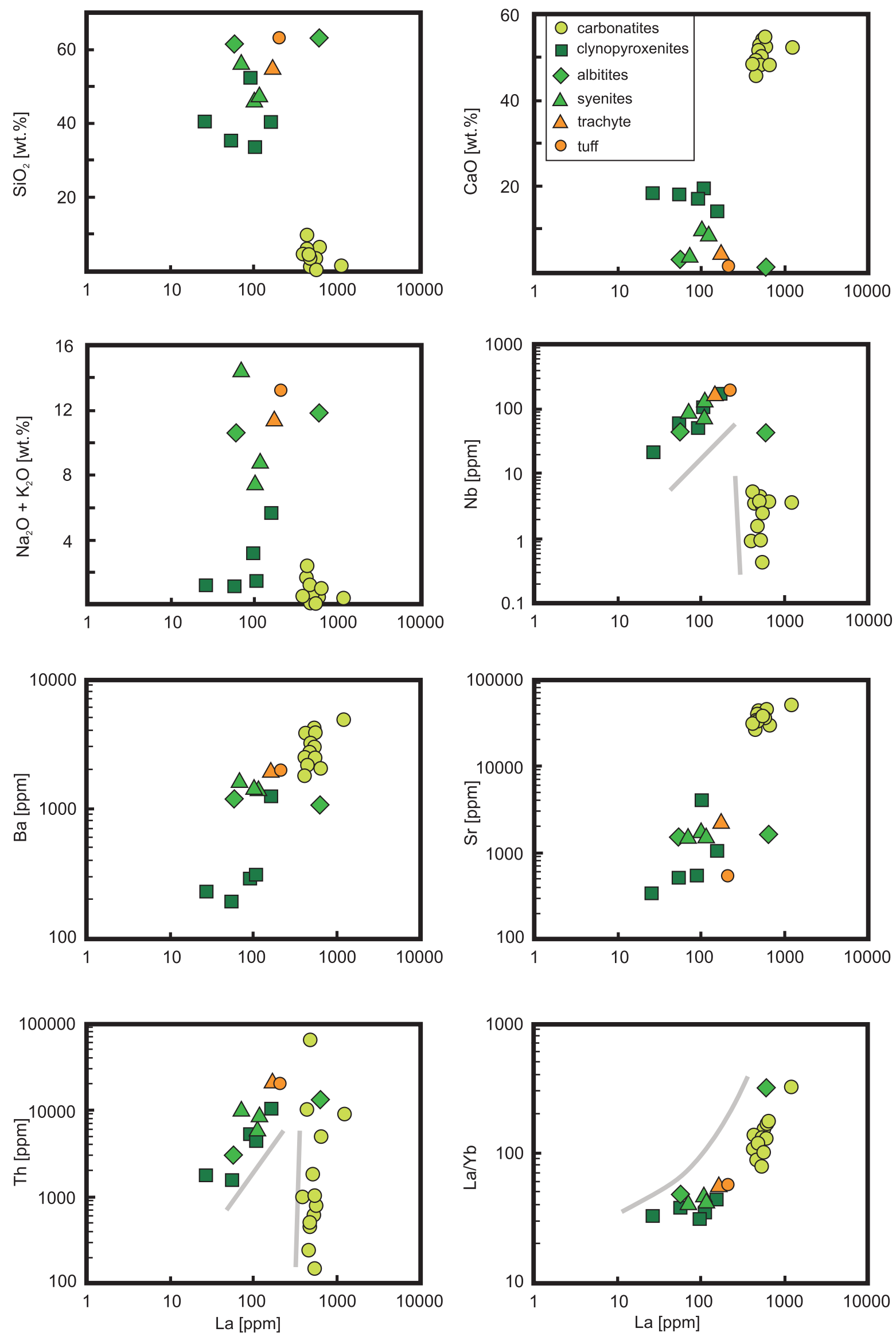

Fig. 7. Trace-element and selected major elements versus La binary diagrams of the Tajno carbonatites and related rocks 


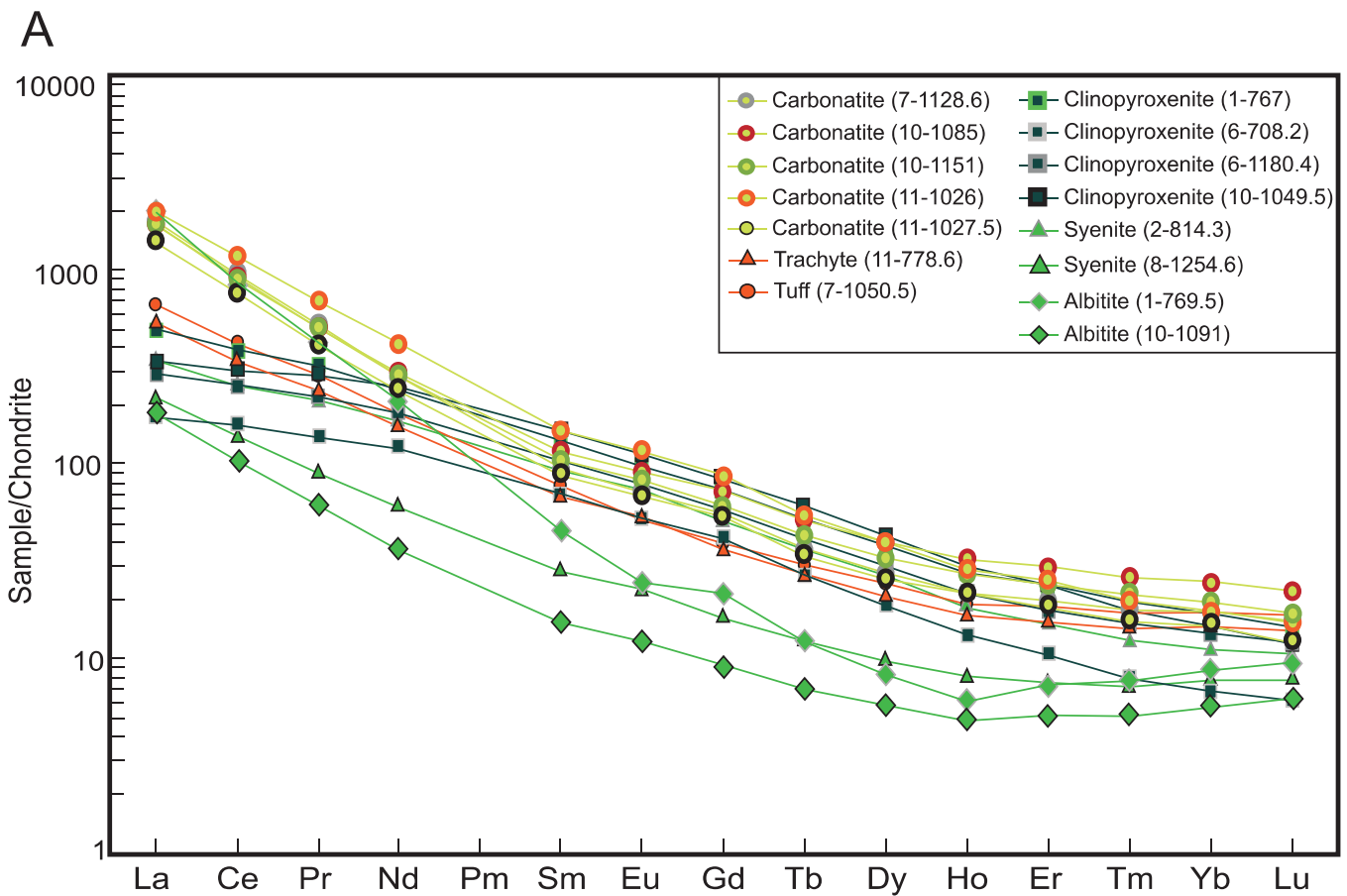

B

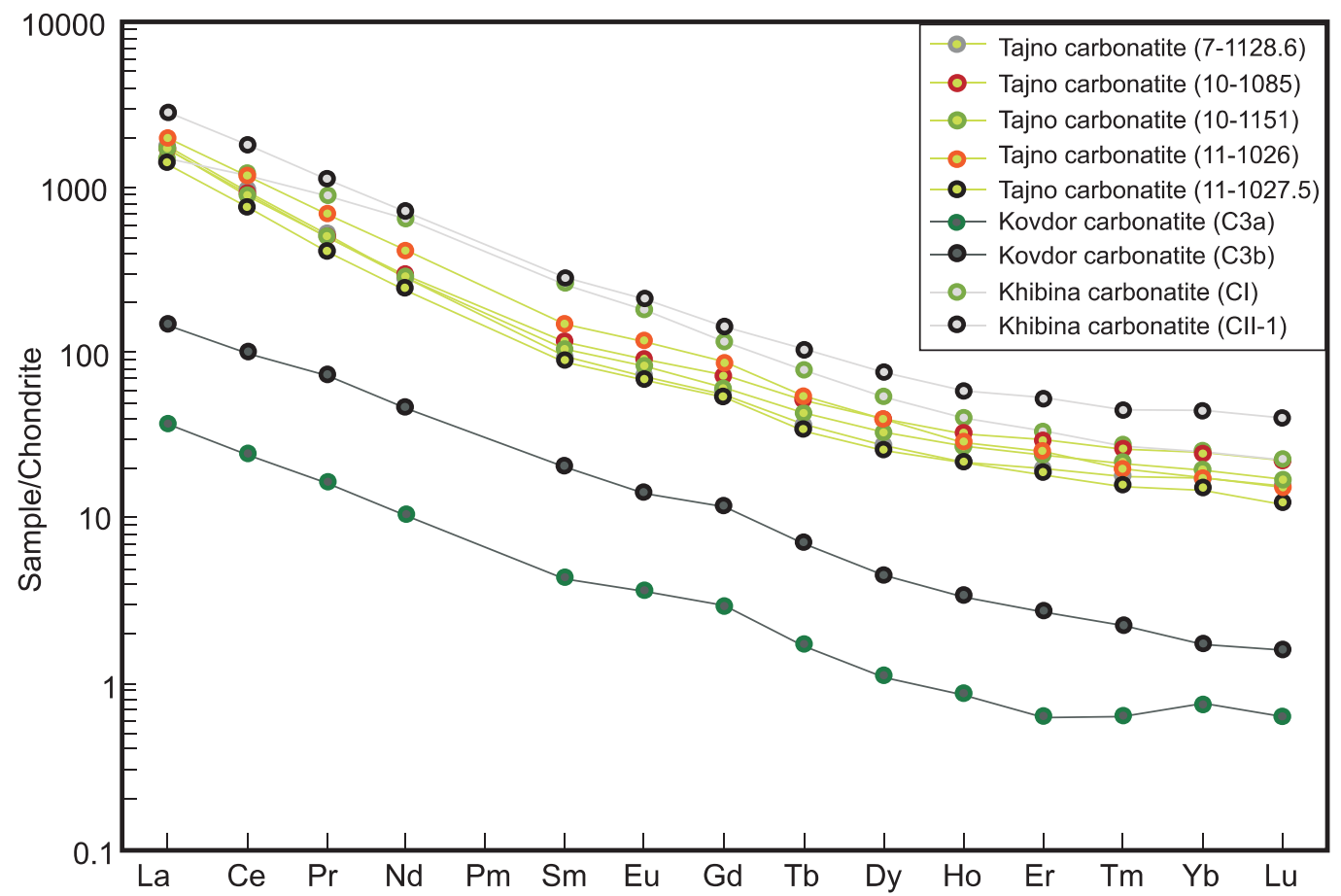

Fig. 8. Chondrite-normalized REE abundance patterns

A - carbonatites and associated silicate rocks from Tajno; B - comparison of the Tajno carbonatites with those of the Kovdor and Khibiny intrusions of the Kola Peninsula (Verhulst et al., 2000;

Zaitsev et al., 2014); chondrite values from Boynton (1984)

which reflects the very low modal abundances of $\mathrm{Nb}$-bearing minerals (perovskite and pyrochlore groups). As a consequence, the $\mathrm{Nb} / \mathrm{Y}$ ratio is always $<1$ (Appendix 1 ) implying derivation from the mantle rather than from metasomatic fluids (Pilet et al., 2004). Nevertheless, one sample contains 200 ppm $\mathrm{Nb}$. Clinopyroxenites and syenites have significantly higher content of $\mathrm{Nb}$ (21 to $165 \mathrm{ppm}$ ) presumably included in titanite.
The Tajno carbonatites are highly enriched in LILE (Sr, Ba and LREE) compared to the silicate rocks. La enrichment is well-correlated with the enrichments of $\mathrm{Ca}, \mathrm{Sr}$ and $\mathrm{Ba}$. The $\mathrm{Sr}$ content is particularly high $(28,000-49,000 \mathrm{ppm})$, which reflects the occurrence of numerous strontianite inclusions in the calcite grains. The Th and $U$ contents in carbonatites are generally low (0.14-10.5 ppm and $<1 \mathrm{ppm}$, respectively) except for one sample (65 ppm Th and 22.9 ppm U). The HFS elements ( $\mathrm{Nb}, \mathrm{Ta}$, 
A

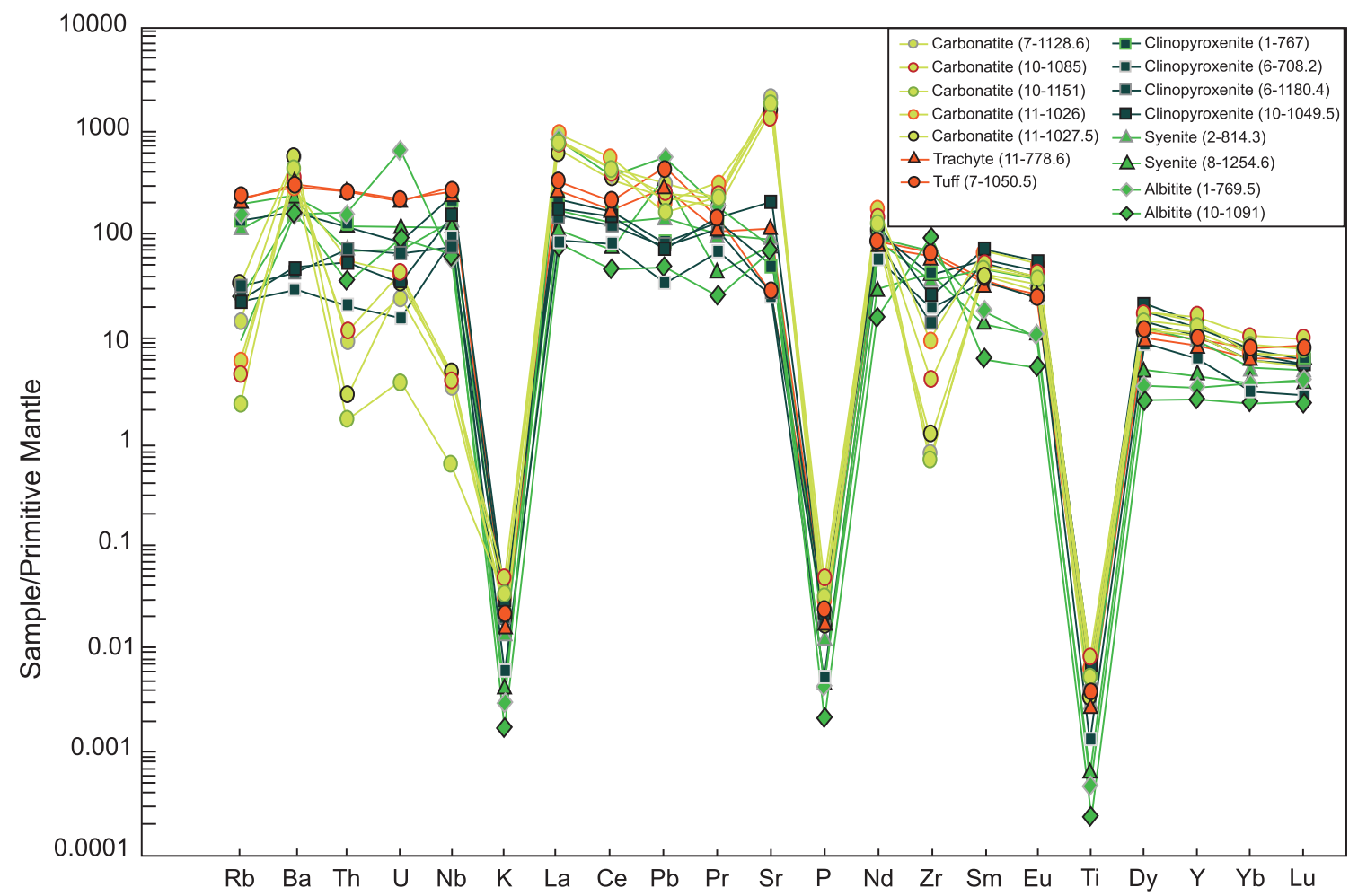

B

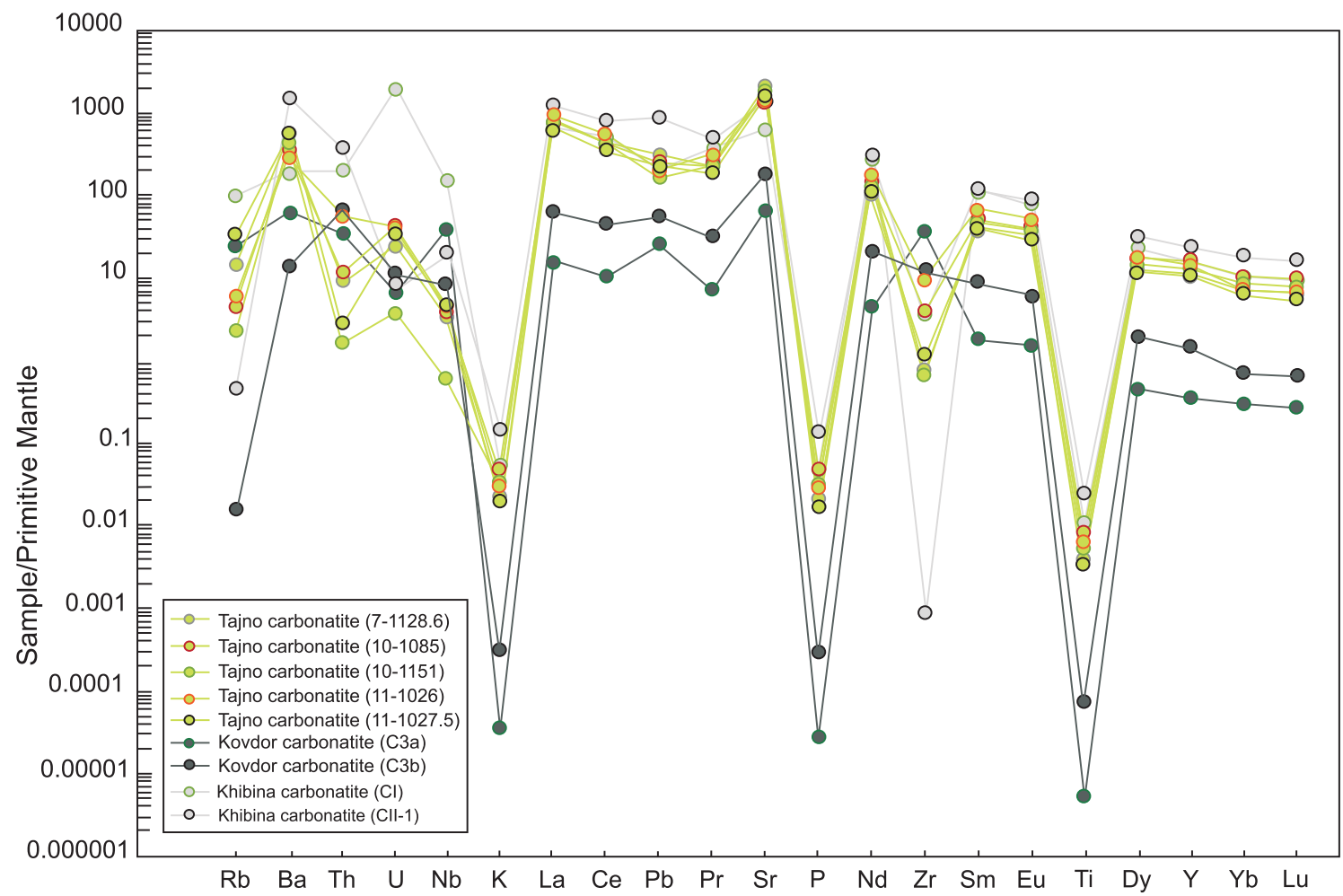

Fig. 9. Primitive mantle (PM)-normalized trace-element abundance patterns

A - carbonatites and associated silicate rocks from Tajno;

B - comparison of the Tajno carbonatites with selected carbonatites

from Kovdor and Khibiny; PM mantle values from McDonough and Sun (1995) 
$\mathrm{Zr}$, Hf, and $\mathrm{Ti}$ ) are typically depleted relative to the LREE (see Fig. 9A).

The chondrite-normalized REE abundances of Tajno rocks are shown in Figure 8. All samples have LREE-enriched patterns without $\mathrm{Ce}$ and $\mathrm{Eu}$ anomalies. Carbonatites have significantly higher $(\mathrm{La} / \mathrm{Yb})_{\mathrm{N}}$ ratios $(60-220)$ than the clinopyroxenites (32 to 57) and the $L a_{N}$ abundances are in the range of 1870-2650. The sum of the REE contents ranges from 1307 to 2013 ppm for carbonatites and from 318 to 754 ppm for clinopyroxenites.

REE-bearing minerals (as the accessory HFSE-rich minerals; Chakhmouradian, 2006) are distributed very heterogeneously in the thin carbonatite dykes/veins and in the carbonatitic cement of the chimney breccia, so that it is extremely difficult to estimate the average REE content. Kubicki (1992) reported the $\mathrm{REE}_{2} \mathrm{O}_{3}$ content varying between 0.1 and $0.5 \%$, while Ryka (1992) gave an average of $0.71 \%$ (ranging from 0.2 to $1.3 \%$ ). Ryka (1992) also noted that some rare carbonatites (not studied in this paper) have the $\mathrm{REE}_{2} \mathrm{O}_{3}$ content ranging from 2 to $9.5 \%$. In this study, the REE content varies from 1307 to $2013 \mathrm{ppm}$. Carbonatite samples are also extremely enriched in fluorine (up to $15 \% \mathrm{~F}$ ), suggesting that the REEs can be hosted in fluorites of low-temperature origin. The low-temperature hydrothermal F-rich fluids could easily mobilize REE, resulting in their enrichment.

On the primitive mantle-normalized multi-element diagram (Fig. 9), all Tajno rocks broadly display the same pattern of strong incompatible element enrichments relative to the primitive mantle, and strong negative anomalies for $\mathrm{Rb}, \mathrm{K}, \mathrm{P}$ and $\mathrm{Ti}$ and, to a lesser extent, for $\mathrm{Zr}$.

A significant feature is the low $\mathrm{Nb}$ content in Tajno carbonatites (119 ppm on average; Ryka, 1992) compared to the av- erage carbonatite (1204 ppm, but ranging up to 15000 ppm; Woolley and Kempe, 1989).

\section{ISOTOPE GEOCHEMISTRY}

\section{Sr, Nd AND Pb RADIOGENIC ISOTOPE GEOCHEMISTRY}

The $\mathrm{Sr}$ and $\mathrm{Nd}$ isotopic compositions have been measured on a selection of 25 samples from different boreholes that crosscut the Tajno Massif: 13 carbonatites, 5 clinopyroxenites, 3 syenites, 2 albitites and 2 volcanic rocks (tuff and trachyte). The data are given in Appendix 3 and plotted in the $\mathrm{Nd}-\mathrm{Sr}$ isotopic diagram (Fig. 10). The initial isotopic compositions have been recalculated for an age of $348 \mathrm{Ma}$ (the zircon U-Pb age of albitite; see above and Demaiffe et al., 2013). Carbonatites selected from three boreholes (Tajno IG 7, IG 8, IG 11) are remarkably homogeneous: the initial ${ }^{87} \mathrm{Sr}{ }^{186} \mathrm{Sr}$ ratios fall in the very narrow range of $0.70370-0.70380$ and the $\varepsilon \mathrm{Nd}(\mathrm{t})$ values range from +3.3 to +0.7 . Clinopyroxenites have slightly, but systematically higher initial $\mathrm{Sr}$ isotopic ratios (from 0.7039 to 0.7048 ) and more dispersed $\varepsilon N d$ values (from +5.73 to -0.68 ). The isotopic compositions of the syenites are completely overlapping those of the clinopyroxenites, suggesting their comagmatic/cogenetic origin. Albitites, although interpreted as metasomatic rocks, are comparable to carbonatites.

Bell and Ryka (unpubl. data, 1992) measured a few carbonatites, syenites and separated apatites: their values are in very good agreement with our data. They also measured the isotopic compositions of five fluorites: the recalculated compositions at

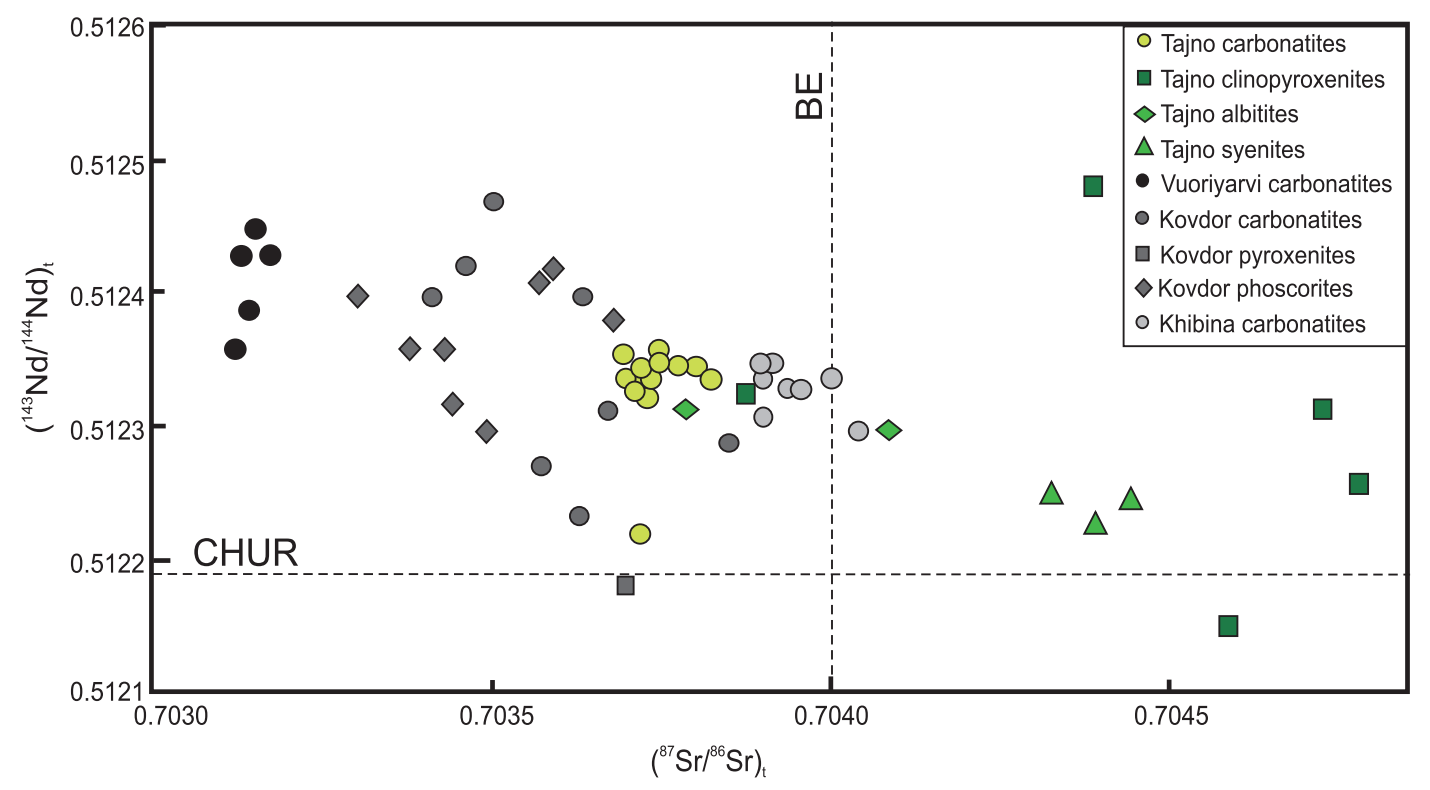

Fig. 10. Nd-Sr isotopic diagram

The initial $\varepsilon N d$ and ${ }^{87} \mathrm{Sr} /{ }^{86} \mathrm{Sr}$ isotopic ratios of the Tajno carbonatites and associated silicate rocks have been recalculated at $348 \mathrm{Ma}$. Comparison with the data of the Vuoriyarvi, Kovdor and Khibina intrusions of the Kola Peninsula (data from: Verhulst et al., 2000; Brassinnes et al., 2003; Zaitsev et al., 2014) 
$380 \mathrm{Ma}\left({ }^{87} \mathrm{Sr} /{ }^{86} \mathrm{Sr}: 0.7038\right.$ to $0.7040 ; \varepsilon \mathrm{Nd}(\mathrm{t}):+2.34$ to -0.50$)$ fall in the range of Tajno carbonatites.

The $\mathrm{Pb}$ isotopic compositions have been measured for 11 Tajno samples ( 7 carbonatites, 2 clinopyroxenites and 2 syenites). The seven carbonatites are tightly clustered around ${ }^{206} \mathrm{~Pb} /{ }^{204} \mathrm{~Pb}=17.90$ to $18.50 ;{ }^{207} \mathrm{~Pb} /{ }^{204} \mathrm{~Pb}=15.49$ to 15.53 and ${ }^{208} \mathrm{~Pb} /{ }^{204} \mathrm{~Pb} \sim 37.6-38$. The two syenites have slightly higher ${ }^{206} \mathrm{~Pb} /{ }^{204} \mathrm{~Pb}$ ratios, around $19.0-19.2$.

\section{AND O STABLE ISOTOPE SIGNATURES}

Carbonatites, especially when they occur as small veins or small bodies, are easily subjected to secondary alteration processes which can modify their primary stable ( $\mathrm{C}$ and $\mathrm{O}$ ) isotope composition. Besides early Rayleigh fractionation processes, $\mathrm{CO}_{2}$ degassing and further sub-solidus re-equilibration (Tichomirova et al., 2012 and references therein), carbonatites can be affected by late-stage complex interaction processes with various hydrous and/or carbonate-bearing fluids under variable conditions both in the deep and upper crust. Moreover, infiltration of late carbonatite melts is a common process within many alkaline intrusions that can modify the primary geochemical distributions and isotopic signatures of carbonates and even of silicate phases like zircon. This is well-evidenced by stable $\mathrm{C}$ and $\mathrm{O}$ isotope compositions of the Tajno carbonates.

During early investigations, bulk-rock carbonate fractions from Tajno carbonatites were analysed for $\mathrm{C}$ and $\mathrm{O}$ isotope compositions by the conventional method at UMCS of Lublin (Ryka, 1992): $\delta^{13} \mathrm{C}$ and $\delta^{18} \mathrm{O}$ values range from -5.91 to
$+1.31 \%$ and from 7.66 to $13.86 \%$, respectively. Stable isotope compositions of bulk-rock carbonates are difficult to interpret due to the possible presence of several carbonate generations and of secondary alteration processes.

New investigations on selected single calcite grains have been performed by the SHRIMP ion microprobe with secondary ion mass spectrometry (SIMS) technique. To characterize the isotopic composition variations of the various generations of calcite, a complex carbonatite sample was collected from the chimney breccia at $570 \mathrm{~m}$ depth in the Tajno IG 4 borehole. Seventy-nine analyses have been obtained: summary and average data are reported in Table 1. The whole data set is compiled in Appendix 4 as supplementary material. The $\delta^{13} \mathrm{C}$ values range from $-9.33 \pm 0.44 \%$ o to $+6.49 \pm 0.48 \%$ o (average $-2.2 \%$ o \pm 1 ) and the $\delta^{18} \mathrm{O}$ are from $5.86 \pm 0.11 \%$ to $24.39 \pm 0.12 \%$ (average $13.5 \pm 1 \% 0$ ). These quite broad ranges suggest the coexistence of three generations of calcite within the upper part of the chimney breccia.

These results are compared (Fig. 11) with the field of "primary igneous carbonatites" (PIC) (Taylor et al., 1967), which represents the unmodified "primary isotope compositions" of typical carbonatites and the large domain of Phanerozoic limestones (Bell and Simonetti, 2010). The $\delta^{18} \mathrm{O}$ and $\delta^{13} \mathrm{C}$ values for PICs range from 6 to $10 \%$ and from -4 to $-8 \%$, respectively. Keller and Hoefs (1995) measured narrower ranges from 5.5 to $7 \%$ and from -7 to $-5 \%$ respectively for fresh and unaltered natrocarbonatites from Oldoinyo Lengai volcano (OL in Fig. 6). Pandit et al. (2002) consider that OL represents the undergassed, uncontaminated mantle composition. This interpretation, however, is not unanimously accepted; some authors (e.g., Nielsen and Veksler, 2002) have shown that

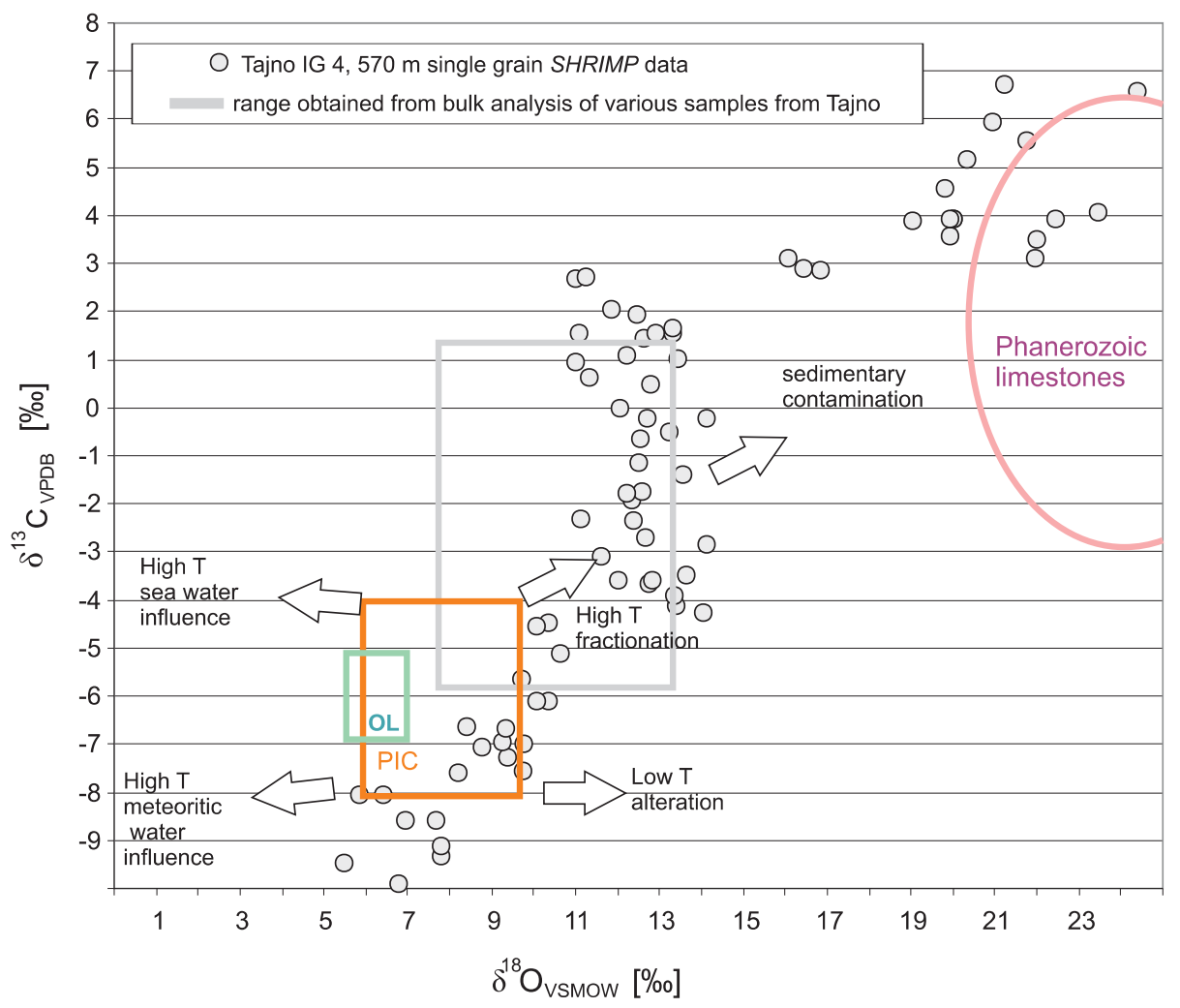

Fig. 11. Carbon $\left(\delta^{13} \mathrm{C}_{\mathrm{PDB}}\right)$ and oxygen $\left(\delta^{18} \mathrm{O}_{\mathrm{Smow}}\right)$ isotopic compositions (in \%o) of the Tajno chimney breccia carbonatites, measured on single carbonate grains by ion microprobe 
natrocarbonatites of OL do not correspond to the HT liquidus mineral assemblage but more probably to "a cognate fluid condensate".

\section{GEOCHRONOLOGY}

\section{PREVIOUS DATA}

The emplacement age of the Tajno Massif was first obtained by the K-Ar method on separated alkali feldspars; Depciuch et al. (1975) gave age estimates of $\sim 327$ and $\sim 289$ Ma on feldspars from coarse-grained syenite and microsyenite, respectively. Demaiffe et al. (2013) determined emplacement ages for carbonatite based on zircons extracted from carbonate-rich-pockets in an albitite on the one hand and on pyrrhotite selected from a carbonatite vein on the other. The ages measured by both methods (U-Th-Pb on zircon and Re-Os on pyrrhotite) cluster in the narrow range of 354-345 Ma, which corresponds to the Tournaisian (Early Carboniferous). These ages are significantly younger than the Late Devonian age (380-360 Ma) of the numerous intrusions of the Kola Peninsula alkaline and carbonatite province in NW Russia and Karelia (Kramm et al., 1993; see review and discussion in Downes et al., 2005).

\section{NEW DATA}

\section{AGE OF THE COUNTRY ROCKS OF THE TAJNO AREA}

The Tajno ultramafic and alkaline plutonic body and its associated carbonatites were emplaced into a Precambrian crystalline basement consisting of orthogneisses, quartzites and schists. The geochronology of the crystalline basement within the MD has been reviewed by Krzemińska (2010).

Two boreholes located in the close vicinity of the Tajno complex have been used in this study. Zircons were separated from two strongly deformed felsic orthogneisses at $706 \mathrm{~m}$ depth in the Bargłów IG 2 borehole and at $894 \mathrm{~m}$ in the Tajno IG 5 borehole (Fig. 1). The extracted zircon grains are mostly transparent, massive, euhedral to subhedral crystals. Cathodoluminescence investigations show a concentric oscillatory zonation with thin metamorphic overgrowths.

Six zircon grains (analytical data reported in Appendix 2) from Bargłów IG 2 and five from Tajno IG 5 yield nearly concordant (within analytical uncertainty) but slightly scattered (Fig. $12 \mathrm{~A}$, B) U-Th-Pb ages of $1838 \pm 17 \mathrm{Ma}(\mathrm{MSWD}=0.14)$ and $1839 \pm 20 \mathrm{Ma}(\mathrm{MSWD}=0.30$ ), respectively, which is interpreted as the crystallization age of igneous, probably volcanogenic protoliths. The age determinations and chemistry (Bogdanova et al., 2015; Krzemińska et al., 2017) of the available Paleoproterozoic igneous rocks from the Mazowsze Domain in Poland to central Lithuania suggest that this part of the EEC was an active continental margin established at 1.86-1.84 Ga, while some rock complexes in its western and southern parts (including the gabbro from Łomża) were emplaced later at 1.82-1.80 $\mathrm{Ga}$ (Krzemińska et al., 2005). The formation and evolution of the host rocks of the Tajno complex can be related to late Svecofennian orogenic processes (Krzemińska, 2010).

\section{AGE OF THE TAJNO ALKALINE COMPLEX}

In practice, dating carbonatite-associated ultramafic and alkaline complexes is a great analytical challenge. This is particularly true for the Tajno complex, as the carbonatitic veins do not contain typical U-Th-rich accessory minerals (e.g., pyrochlore, perovskite, baddeleyite) that are commonly used to date carbonatites and kimberlites (e.g., Cox and Wilton, 2006).

However, U-Th-Pb age determinations have been performed on zircons extracted from metasomatic albitite that is closely associated with carbonate-rich pockets and/or diffuse veinlets (Demaiffe et al., 2013). Zircon grains are large (>200 $\mu \mathrm{m}$ ), generally euhedral to subhedral, with oscillatory zoning; they have thick, porous, deeply corroded overgrowths, which suggested secondary processes. The $\mathrm{U}$ content is high, 845-1150 ppm.

The measurements of 12 spots on six grains with quite variable $U$ and Th contents (81-715 ppm $U$ and 78-720 ppm Th) provided isotopic ratios close to concordia or slightly discordant. They yielded an intercept age of $348 \pm 15 \mathrm{Ma}$ on the TeraWasserburg diagram (Demaiffe et al., 2013). Using the same data set, we have selected the most concordant spots from four grains; they yield a concordia age at $346.8 \pm 14 \mathrm{Ma}$ (95\% confidence) and MSWD = 0.30 (Fig. 12C).

For comparison, zircon age determinations for the neighbouring Ełk syenite massif and Pisz gabbro-syenite massif gave ages at $347.7 \pm 7.9 \mathrm{Ma}$ and $345.5 \pm 5.1 \mathrm{Ma}$, respectively (Demaiffe et al., 2013).

Fine-grained pyrrhotite (associated with pyrite mineralization) extracted from a carbonatite vein (Tajno IG 10 borehole, depth $1047.0 \mathrm{~m}$ ) was used to obtain a Re-Os age. The Re concentration of the pyrrhotite was $17.06 \pm 0.03 \mathrm{ppb}$; the total Os content was $0.096 \pm 0.007 \mathrm{ppb}$. As the common Os was very low ( $\left({ }^{192} \mathrm{Os:} 0.0056 \mathrm{ppb}\right)$, a Re-Os age of $348 \mathrm{Ma}$ was obtained, assuming an initial ${ }^{187}$ Os/ $/{ }^{188}$ Os of 0.2 (Demaiffe et al., 2013). The analytical error, combined with the ${ }^{187} \mathrm{Re}$ decay constant, put the uncertainty of the Re-Os age at $<0.5 \%(<\sim 1.7 \mathrm{Ma})$.

This new recalculated zircon U-Pb age and the Re-Os pyrrhotite age for The Tajno Massif are within the Early Carboniferous range of previously published data. Age consistency suggests synchronous formation of the three alkaline-carbonatite complexes.

\section{DISCUSSION}

The Tajno Massif, as most carbonatite-bearing intrusions, is located within stable intra-plate settings controlled by deep fracture zones and rifting.

The radiogenic $(\mathrm{Sr}, \mathrm{Nd}$, and $\mathrm{Pb})$ and stable $(\mathrm{C}$ and $\mathrm{O})$ isotopic compositions of representative Tajno rocks provide evidence for a mantle source of the parental magma (or magmas) of the Tajno complex.

Indeed, all initial $\mathrm{Nd}-\mathrm{Sr}$ isotope data of the Tajno carbonatites plot in the depleted mantle quadrant $\left(\varepsilon N d>0 ;{ }^{87} \mathrm{Sr} /{ }^{86} \mathrm{Sr}\right.$ $<0.7040$ ) of the $\mathrm{Nd}-\mathrm{Sr}$ diagram, which means that the parental magma was derived most probably from an Rb- and LREE-depleted upper mantle source. This can be easily explained because carbonatites have much higher $\mathrm{Sr}(30,000$ up to $49,000 \mathrm{ppm}$ ) and $\mathrm{Nd}$ (150 to $230 \mathrm{ppm}$ ) abundances than aver- 

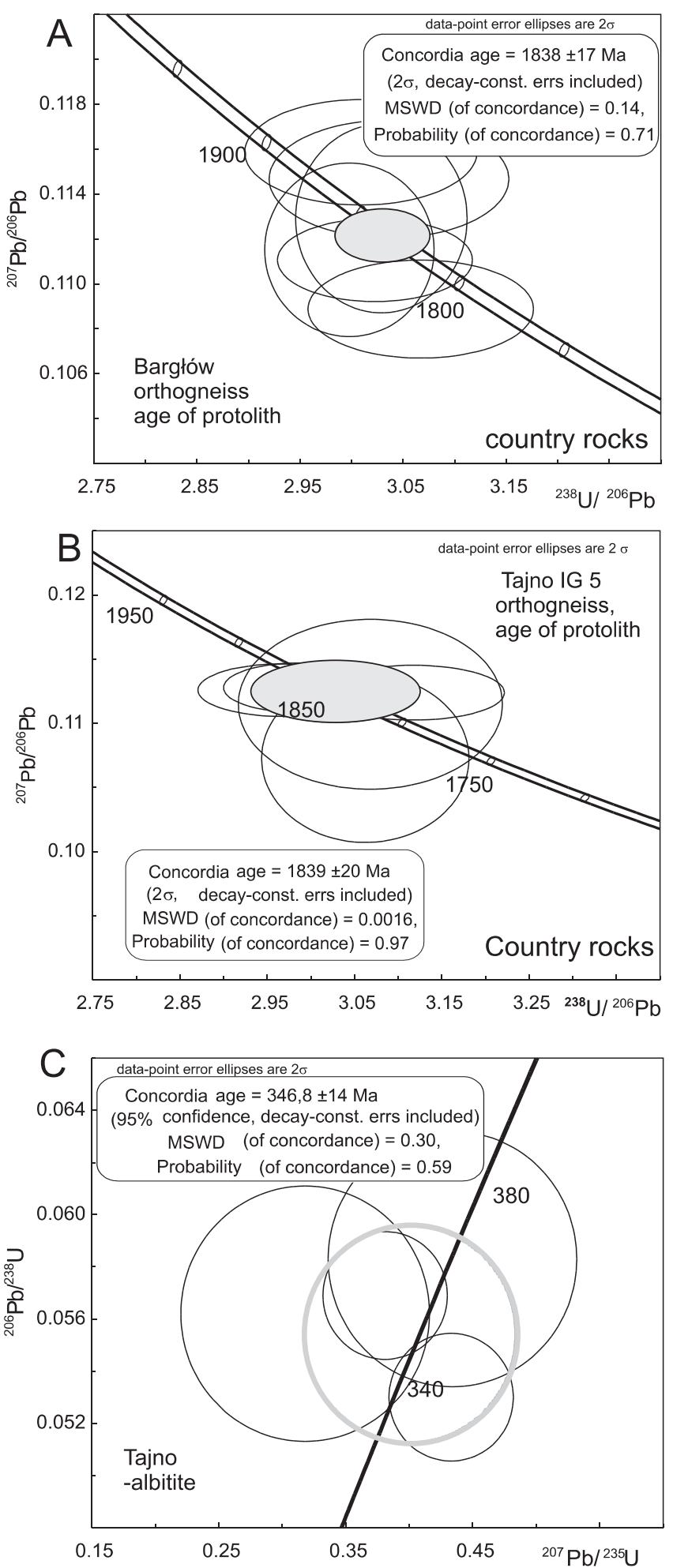

Fig. 12. Zircon ages for the Tajno area

A - Tera-Wasserburg diagram for the country rock orthogneiss of the Bargłów IG 2 borehole, B - Tera-Wasserburg diagram for the country rock orthogneiss of the Tajno IG 5 borehole; $\mathbf{C}$ - Wetherill diagram for the Tajno IG 10 albitite (sample 10-1091). The concordia age was recalculated using selected zircon isotopic ratios from the data set published by Demaiffe et al. (2013). This age is constrained on four zircon grains and spots: $7.3,8.2,9.1,10.1$ age crustal materials. There is a slight but significant isotopic difference between the carbonatites and the associated alkaline silicate rocks (clinopyroxenites and syenites): the later still have positive initial $\varepsilon \mathrm{Nd}$ values, but their $\mathrm{Sr}$ isotopic ratios tend to be higher (0.7039-0.7048). This implies either that carbonatites and silicate rocks were derived from slightly different mantle sources (heterogeneous mantle) or that the silicate rocks were contaminated (more specifically $\mathrm{Sr}$ ) by crustal materials during their emplacement or during crystallization.

The depleted mantle source signature of the Tajno carbonatites and of the numerous Kola carbonatites and alkaline complexes (i.g. Zaitsev and Bell, 1995; Verhulst et al., 2000; Brassinnes et al., 2003; Bell and Rukhlov, 2004; Downes et al., 2005 ) is difficult to reconcile with the strong LILE and LREE enrichment observed in these rocks. This would require a very low degree of partial melting of the mantle or would indicate a recent (Late Proterozoic/Early Phanerozoic?) metasomatic enrichment of the mantle source. The lithospheric structure beneath the East European Craton (Artemieva, 2003) suggests the existence of such a metasomatic event during a rifting stage that occurred between $1 \mathrm{Ga}$ and $650 \mathrm{Ma}$.

It is well-known (Bell and Tilton, 2002; Bell and Rukhlov, 2004; Downes et al., 2005) that the isotopic compositions of carbonatites and alkaline complexes are quite similar to those of oceanic basalts (OIB in general) and plot close to the FOZO ("focal zone") deep mantle reservoir which is considered as relatively primitive.

The range of $\mathrm{Sr}-\mathrm{Nd}$ isotopic compositions of the Tajno fluorites (Bell and Ryka, unpubl. data, 1992) is completely overlapping the narrow range of Tajno carbonatite values (this paper), which suggests that fluorite crystallized directly from the carbonatite melt as was also reported by Bühn et al. (2002) for the Cretaceous Okorusu carbonatite and associated fluorites from Namibia. Jago and Gittins (1991) have shown experimentally that $8 \%$ of fluorine can lower the melting and liquidus temperature of carbonatite melts.

The Tajno carbonatites have relatively low ${ }^{206} \mathrm{~Pb} /{ }^{204} \mathrm{~Pb}$ values, $<18.5$. This infers that the participation of the highly radiogenic HIMU mantle component can be ruled out. The present-day $\mathrm{Pb}$ isotopic compositions of the Tajno rocks plot slightly to the right of the geochron (not shown) and the carbonatites fall within the FOZO domain, which strengthens the conclusions derived from $\mathrm{Sr}$ and $\mathrm{Nd}$ data.

A closer look at the position of the Tajno calcite samples in the $\mathrm{C}-\mathrm{O}$ isotope diagram (Fig. 11) suggests the possible existence of three groups of calcite:

- some calcites ( 25\%) plot in, or close to, the PIC domain.

They can be considered typical mantle-derived carbonatites;

- a majority of calcites $(>50 \%)$ show both higher $\delta^{18} \mathrm{O}(10$ to

$15 \%)$ and $\delta^{13} \mathrm{C}(-5$ to $+2 \%$ ) values. Contrary to what is often observed, there is a large range of $\mathrm{C}$ isotopic composition for rather limited $\mathrm{O}$ isotopic variations;

- a group of calcites ( 25\%) with still higher $\delta^{18} \mathrm{O}$ (15 to $24 \%$ ) and $\delta^{13} \mathrm{C}$ (3 to $7 \%$ ), which partly overlaps the field of Phanerozoic limestones.

Alternatively, one could suggest that the isotopic compositions of Tajno calcites record rather a continuous shift of composition from the primary magmatic values (inside or close to $\mathrm{PIC}$ ) towards the high $\mathrm{C}$ and $\mathrm{O}$ values that characterized the Phanerozoic limestones. The passage of group 1 to group 2 could be indicative either of Rayleigh fractionation during magmatic differentiation (fractional crystallization, degassing) or to secondary hydrothermal processes. The passage to group 3 would record an isotopic exchange during fluid interactions 
and/or a fluid mixing with lower-temperature fluids (below $300^{\circ} \mathrm{C}$ ) or meteoric waters, at different temperatures and with various $\mathrm{H}_{2} \mathrm{O} / \mathrm{CO}_{2}$ ratios. Contamination of the late-stage Tajno fluids by limestone-derived fluids could also be invoked.

Open-system $\mathrm{CO}_{2}$-degassing and concomitant Rayleigh fractionation processes, as well as low-temperature magmatic fluid-related processes, have the potential to change primary stable isotope compositions, as illustrated by arrows in the $\mathrm{C}-\mathrm{O}$ diagram (Fig. 11).

Tajno carbonatites are enriched in sulphur with an average $\mathrm{SO}_{3}$ content of $4.03 \%$ (Ryka, 1992), which is much higher than the average $(0.41 \% \mathrm{~S})$ given by Woolley and Kempe (1989). It thus appears that the parental magma of the Tajno complex was strongly enriched in $\mathrm{F}$ and $\mathrm{S}$, but relatively poor in $\mathrm{P}$.

Considering the close proximity in both geographical location (on the East European Craton) and emplacement ages (Late Paleozoic) between the Tajno alkaline-carbonatite complex of NE Poland and the numerous intrusions of the Kola Province (NW Russia and Finland), it is interesting to compare these two occurrences. The main difference between both complexes is the disproportion in the size and the scale of the processes. Petrographic similarities are obvious between the Tajno rocks and the Kola rocks: they both contain abundant ultramafic cumulates (essentially clinopyroxenites), various syenites (rocks of the ijolite-melteigite series) and several generations of carbonatites, mainly calciocarbonatites with subordinate magnesiocarbonatites and ferrocarbonatites. Subtle differences can nevertheless be noted: dunites (called "olivinites" by Russian scientists because they can contain abundant magnetite), associated with clinopyroxenites in Kola, and melilitic rocks do not occur in Tajno; phoscorites are typically related to carbonatites in Kola (Wall and Zaitsev, 2004), but are not observed in Tajno. Some mineralogical differences have also been reported (see Demaiffe et al., 2005). Feldspathoids are significantly less abundant in Tajno rocks where syenites predominate over agpaitic nepheline-syenites (the reverse is observed in Kola). Tajno carbonatites do not contain foids but alkali feldspars instead. Interestingly, perovskite is mined as loparite $(\mathrm{Ce}, \mathrm{Na}, \mathrm{Ca})_{2}(\mathrm{Ti}, \mathrm{Nb})_{2} \mathrm{O}_{6}$ in Kola (Lovozero intrusion), but it is absent in Tajno, while titanite is abundant, occurring as a cumulus phase in the Tajno clinopyroxenites. These mineralogical differences would suggest that the silica activity was higher in the Tajno parental magma than in the Kola ones. The typical $\mathrm{Zr}$ - and/or Nb-rich minerals (baddeleyite, zirconolite, pyrochlore, perovskite), frequent in many carbonatites worldwide, are extremely rare in Tajno. By contrast, fluorite is common in Tajno carbonatites, especially in the chimney breccia, where its modal abundance can be as high as 50 wt.\% (Ryka, 1992).

The REE content of the Tajno carbonatites varies from 1307 to $2013 \mathrm{ppm}$. In the Kola carbonatites, the REE content is also quite variable from massif to massif. The Turiy Mts. and Kovdor carbonatites (Verhulst et al., 2000; Zaitsev et al., 2014) have much lower contents than Tajno, while the Khibina and
Vuoriyarvi carbonatites (Zaitsev et al., 1998; Brassinnes et al., 2003; Zaitsev et al., 2014) have higher contents (Fig. 8B).

\section{CONCLUSIONS}

The Tajno plutonic complex is a multi-phase (differentiated) intrusion that consists mainly of clinopyroxenites (cumulates), syenites, several generations of carbonatite (mainly calciocarbonatites) and numerous volcanic to subvolcanic mafic to felsic dykes.

This intrusion (with two other similar but carbonatite-free massifs: Ełk and Pisz) was identified from detailed magnetic and gravity investigations in NE Poland. It is hidden beneath a thick Meso-Cenozoic sedimentary cover and intruded the Paleoproterozoic $(1.84 \mathrm{Ga}$ ) basement of the Mazowsze Domain formed during the Svecofennian Orogeny (part of the East European Craton) during the Early Carboniferous (348 Ma).

Carbonatites (and, to a lesser extent, the associated alkaline silicate rocks) are strongly enriched in LIL elements (particularly $\mathrm{Sr}, \mathrm{Ba}$ and LREEs), in $\mathrm{F}$ (abundant fluorite) and $\mathrm{S}$, but are relatively poor in HFS elements and notably in $\mathrm{Nb}$. The typical $\mathrm{Nb}$-bearing minerals (pyrochlore) are absent.

Radiogenic ( $\mathrm{Sr}, \mathrm{Nd}$ and $\mathrm{Pb}$ ) and stable $(\mathrm{C}$ and $\mathrm{O})$ isotopic compositions of carbonatites point to a depleted upper mantle source for the parental magma, close to the FOZO domain. This source has probably been enriched by a metasomatic event just before magma generation.

A progressive and continuous shift of stable isotope composition is observed for calcites, from the primary igneous values (inside or close to the PIC box) towards the high $\mathrm{C}$ and $\mathrm{O}$ values, reflecting secondary processes with no significant changes for radiogenic isotopes.

Acknowledgements. This paper is a result of bilateral cooperation grant between Wallonie-Bruxelles International (Brussels) for D. Demaiffe and the Polish Geological InstituteNational Research Institute (Warsaw) for J. Wiszniewska, funded by the CGRI (Belgium and Poland in 2003-2007). This study was also possible thanks to the Polish Geological Institute - National Research Institute project 61.6701.1801.00.0 (geophysical and lithological results). Stable isotope analyses were possible through funding from Ministry of Science and Higher Education PGI-NRI internal grants No. 660.8520.1401.00.0. Analytical assistance with the SHRIMP Ile/MC calibration procedure was provided by Z.J. Czupyt. At ULB (Bruxelles), thanks to $W$. Debouge for chemical preparation of the samples in clean rooms and to P. Hermand for maintenance of the VG Sector 54 mass spectrometer. Sincere thanks to L. Krzemiński for the Tajno borehole profiles drawing. Research Grant from FNRS to $\mathrm{DD}$ is gratefully acknowledged. Editorial reviews by R. MacDonald and B. Bagiński are greatly appreciated, and we thank for professional editorial handling.

\section{REFERENCES}

Ashwal, L., Demaiffe, D., Torsvik, T., 2002. Petrogenesis of Neoproterozoic granitoids and related rocks from the Seychelles: the case for an Andean-type arc origin. Journal of Petrology, 43: 45-83.
Artemieva, I., 2003. Lithospheric structure, composition, and thermal regime of the East European craton: implications for the subsidence of the Russian Platform. Earth and Planetary Science Letters, 213: 429-444. 
Bell, K., ed., 1989. Carbonatites. Genesis and Evolution. Unwin Hyman, London.

Bell, K., Rukhlov, A.S., 2004. Carbonatites from the Kola Alkaline Province: origin, evolution and source characteristics. In: Phoscorites and Carbonatites: from mantle to mine: the key example of the Kola Alkaline Province (eds. F. Wall and A. Zaitsev): 421-455. Mineralogical Society of London.

Bell, K., Tilton, G.R., 2002. Probing the mantle: the story from carbonatites. EOS, Transaction American Geophysical Union, 83: 273-277.

Bell, K., Simonetti, A., 2010. Source of parental melts to carbonatites - critical isotopic constraints. Mineralogy and Petrology, 98: 77-89.

Blakely, R.J., 1995. Potential Theory in Gravity and Magnetic Applications. Cambridge University Press, Cambridge.

Bogdanova, S., Gorbatschev, R., Grad, M., Janik, T., Guterch, A., Kozlovskaya, E., Motuza, G., Skridlaite, G., Starostenko, V., Taran, L., 2006. Archean terrains Palaeoproterozoic reworking and accretion in the Ukrainian Shield, East European Craton. Geological Society Memoirs, 32: 645-654.

Bogdanova, S., Gorbatschev, R., Skridlaite, G., Soesoo, A., Taran, L., Kurlovich, D., 2015. Trans-Baltic Palaeoproterozoic correlations towards the reconstruction of supercontinent Columbia/Nuna. Precambrian Research, 259: 5-33.

Boynton, W.V., 1984. Geochemistry of Rare Earth Elements: meteorite Studies. In: Rare Earth Element Geochemistry (ed. P. Henderson): 63-114. Elsevier, New York.

Brassinnes, S., Demaiffe, D., Balaganskaya, E., Downes, H., 2003. New mineralogical and geochemical data on the Vuorijarvi ultramafic, alkaline and carbonatitic complex (Kola Region, NW Russia). Periodico di Mineralogia, 72: 79-86.

Brassinnes, S., Wiszniewska, J., Demaiffe, D., 2005. A LA-ICP-MS study of carbonates from late-stage carbonatite veins in the Tajno massif (Poland). Mineralogical Society of Poland -Special Papers, 26: 25-28.

Bühn, B., Rankin, A.H., Schneider, J., Dulski, P., 2002. The nature of orthomagmatic, carbonatitic fluids precipitating REE, Sr-rich fluorite: fluid-inclusion evidence from the Okorusu fluorite deposit, Namibia. Chemical Geology, 186: 75-98.

Carignan, J., Hild, P., Mévelle, G., Morel, J., Yeghicheyan, D., 2001. Routine analyses of trace elements in geological samples using flow injection and low pressure on-line liquid chromatography coupled to ICP-MS: a study of geochemical reference materials BR, DR-N, UB-N, AN-G and GH. Geostandards Newsletters, 25: 187-198.

Chakhmouradian, A.R., 2006. High-field-strength elements in carbonatitic rocks: geochemistry, crystal chemistry, and significance for constraining the sources of carbonatites. Chemical Geology, 235: 138-160.

Cieśla, E., Kosobudzka, I., 1992. Geophysical studies of the Tajno massif. Prace Państwowego Instytutu Geologicznego, 139: $15-18$

Clark, D.A., 1997. Magnetic petrophysics and magnetic petrology: aids to geological interpretation of magnetic surveys. AGSO Journal of Australian Geology and Geophysics, 17: 83-103.

Cox, R.A., Wilton, D.H.C., 2006. U-Pb dating of perovskite by LA-ICP-MS: an example from the Oka carbonatite, Quebec, Canada. Chemical Geology, 235: 21-31.

Demaiffe, D., Wiszniewska, J., Brassinnes, S., 2005. A petrological-geochemical overview of the Tajno carbonatite complex (NE Poland): comparison with the Kola Carbonatite Province (Russia). Mineralogical Society of Poland, Special Papers, 26: 29-35.

Demaiffe, D., Wiszniewska, J., Krzemińska, E., Williams, I.S., Stein, H., Brassinnes, S., Ohnenstetter, D., Deloule, E., 2013. A hidden alkaline and carbonatite province of early Carboniferous age in northeast Poland: zircon U-Pb and pyrrhotite Re-Os geochronology. The Journal of Geology, 121: 91-104.

Depciuch, T., Lis, J., Sylwestrzak, H., 1975. K-Ar age of the rocks of the crystalline basement of north-east Poland (in Polish with English summary). Kwartalnik Geologiczny, 19 (4): 759-779.
Downes, H., Balaganskaya, E., Beard, A., Liferovich, R., Demaiffe, D., 2005. Petrogenetic processes in the ultramafic, alkaline and carbonatitic magmatism in the Kola Alkaline Province: a review. Lithos, 85: 48-75.

Dziedzic, E., 1973. Geochemical studies of intrusive formations. Alkaline-ultrabasic Tajno intrusion. Prace Instytutu Geologicznego, 68: 111-113.

Gaczyński, B., 1978. Utwory karbonatytowe w skałach krystalicznych Tajna (in Polish). Ph.D. thesis, Instytut Geologiczny, Warszawa.

Jago, B.C., Gittins, J., 1991. The role of fluorine in carbonatite magma evolution. Nature, 349: 56-58.

Juskowiak, O., 1973. Intrusive formations of basic and alkaline rocks. Tajno alkaline-ultramafic intrusion (in Polish with English summary). Prace Instytutu Geologicznego, 68: 104-108.

Katz, K., Keller, J., 1981. Comb-layering in carbonatite dykes. Nature, 294: 350-352.

Keller, J., Hoefs, J., 1995. Stable isotope characteristics of recent natrocarbonatites from Oldoinyo Lengai. In: Carbonatite Volcanism (eds. K. Bell and J. Keller): 113-123. Springer, Berlin.

Kogarko, L., Kononova, V.A., Orlova, M.P., Woolley, A.R., 1995 Alkaline Rocks and Carbonatites of the World. Part 2. Former USSR. Chapman and Hall, London.

Kozłowski, A., Wiszniewska, J., Sikorska, M., 2005. Fluid inclusions and cathodoluminescence of fluorite from carbonatites of the Tajno Massif, NE Poland. Mineralogical Society of Poland Special Papers, 26: 1-7.

Kramm, U., Kogarko, L., Kononova, V.A., Vartiainen, H., 1993 The Kola alkaline province of $\mathrm{CIS}$ and Finland. Precise $\mathrm{Rb}-\mathrm{Sr}$ ages define 380-360 Ma age range for all magmatism. Lithos, 30: $33-44$.

Królikowski, C., Petecki, Z., 1995. Gravimetric Atlas of Poland. Polish Geological Institute, Warsaw.

Królikowski, C., Petecki, Z., Żółtowski, Z., 1998. Main structural units in the Polish part of the East-European Platform in the light of gravimetric data (in Polish with English summary). Biuletyn Państwowego Instytutu Geologicznego, 386: 5-58.

Krystkiewicz, E., Krzemiński, L., 1992. Petrology of the alkaline-ultrabasic Tajno massif. Prace Państwowego Instytutu Geologicznego, 139: 19-35.

Krzemińska, E., 2010. Geochemical and isotopic reconstruction of the tectonic setting of the Mazowsze Domain in the Precambrian basement of North-Eastern Poland (in Polish with English summary). Prace Państwowego Instytutu Geologicznego, 195: $1-56$.

Krzemińska, E., Williams, I.S., Wiszniewska, J., 2005. A Late Paleoproterozoic subduction-related mafic igneous suite from Łomża, NE Poland. Terra Nova, 17: 442-450.

Krzemińska, E., Krzemiński, L., Petecki, Z., Wiszniewska, J., Salwa, S., Żaba, J., Gaidzik, K., Williams, I.S., Rosowiecka, O., Taran, L., Johansson, C., Pécskay, Z., Demaiffe, D., Grabowski, J., Zieliński, G., 2017. Mapa geologiczna podłoża krystalicznego polskiej cześci platformy wschodnioeuropejskiej 1:1000 000 (in Polish). Państwowy Instytut Geologiczny, Warszawa.

Krzemiński, L., Krzemińska, E., Anczkiewicz, R., Pècskay, Z., 2010. $\mathrm{Sr}$ and $\mathrm{Nd}$ systematics of the Tajno alkaline-ultramafic complex, NE Poland: identification of depleted and enriched components in the subcontinental lithospheric mantle. In: Geochemistry of magmatic rocks: 89-91. XXVII International conference School "Geochemistry of Alkaline Rocks", MoscowKoktebel, Sept. 9-16.

Krzemiński, L., Krzemińska, E., Wiszniewska, J., 2019. Detrital zircon geochronology and provenance of the Proterozoic quartz-rich metasediments of the Mazowsze Domain: source area and regional correlation. Biuletyn Państwowego Instytutu Geologicznego, 474: 59-72.

Kubicki, S., 1992. An outline of geological structure of the Tajno massif. Prace Państwowego Instytutu Geologicznego, 139: 7-13. 
Le Maitre, R.W. ed., 2002. Igneous Rocks. A Classification and Glossary of terms. IUGS, Cambridge University Press.

Ludwig, K.R., 2003. Using Isoplot/Ex, version 2, a geochronological Toolkit for Microsoft Excel. Berkeley Geochronological Center Special Publication, $1 \mathrm{a}$.

Mariano, A.N., 1989. Nature of economic mineralization in carbonatites and related rocks. In: Carbonatites: Genesis and Evolution (ed. K. Bell): 149-172. Unwin Hyman, London.

McDonough, W.F., Sun, S., 1995. The composition of the Earth. Chemical Geology, 67: 1050-1056.

Mitchell, R.H., 2005. Carbonatites and carbonatites. The Canadian Mineralogist, 43: 2049-2068.

Narkiewicz, M., Petecki, Z., 2019. Teisseyre-Tornquist zone evolving approaches and new data (in Polish with English summary). Przegląd Geologiczny, 67: 837-848.

Nielsen, T., Veksler, I., 2002. Is natrocarbonatite a cognate fluid condensate? Contributions to Mineralogy and Petrology, 142: 425-435.

Notholt, A.J.G., Highley, D.E., Deans, T., 1990. Economic minerals in carbonatites and associated alkaline igneous rocks. Transactions of the Institution of Mining and Metallurgy, B99: 59-80.

Pandit, M., Sial, A., Sukumaran, G., Pimente, I.M., Ramasamy, A., Ferreira, V., 2002. Depleted and enriched mantle sources for Paleo-and Neoproterozoic carbonatites of southern India: $\mathrm{Sr}, \mathrm{Nd}, \mathrm{C}-\mathrm{O}$ isotopic and geochemical constraints. Chemical Geology, 189: 69-89.

Petecki, Z., Rosowiecka, O., 2017. A new magnetic anomaly map of Poland and its contribution to the recognition of crystalline basement rocks. Geological Quarterly, 61 (4): 934-945.

Pilet, S., Hernandez, J., Bussy, F., Sylvester, P.J., 2004. Short-term metasomatic control of $\mathrm{Nb} / \mathrm{Th}$ ratios in the mantle sources of intraplate basalts. Geology, 32: 113-116.

Ryka, W., 1992. Geology of the Tajno massif carbonatites. Prace Państwowego Instytutu Geologicznego, 139: 43-78.

Ryka, W., Armbrustmacher, T.J., Modreski, P.J., 1992. Geochemistry and petrology of the alkaline intrusive rocks of the Tajno massif (preliminary report). Prace Państwowego Instytutu Geologicznego, 139: 37-43.

Skridlaite, G., Wiszniewska J., Duchesne, J-C., 2003. Ferropotassic A-type granites and related rocks in NE Poland and S Lithuania: west of the East European Craton. Precambrian Research, 124: 305-326.

Taylor, H.P. Jr., Frechen, J., Degens, E.T., 1967. Oxygen and carbon isotope studies of carbonatites from the Laacher See district, West Germany and the Alnö district, Sweden. Geochimica et Cosmochimica Acta, 31: 407-430.

Tichomirova, M., Whitehouse, M.J., Götze, J., Schulz, B., Belyatsky, B.V., 2012. Different zircon recrystallization types in carbonatites caused by magma mixing: evidence from U-Pb dating, trace element and isotope composition ( $\mathrm{Hf}$ and $\mathrm{O}$ ) of zir- cons from two Precambrian carbonatites from Fennoscandia. Chemical Geology, 35: 173-198.

Verhulst, A., Balaganskaya, E., Kirnarsky, Yu., Demaiffe, D., 2000. Petrological and geochemical (trace elements and Sr-Nd isotopes) characteristics of the Paleozoic Kovdor ultramafic, alkaline and carbonatite intrusion (Kola Peninsula, NW Russia). Lithos, 51: 1-25.

Wall, F., Zaitsev, A.N., 2004. Phoscorites and Carbonatites: from Mantle to Mine. Mineralogical Society, London.

Williams, I.S., Claesson, S., 1987. Isotopic evidence for the Precambrian provenance and Caledonian metamorphism of high grade paragneisses from the Seve Nappes, Scandinavian Caledonides. II. Ion microprobe zircon U-Th-Pb. Contributions to Mineralogy and Petrology, 97: 205-217.

Williams, I.S., Krzemińska, E., Wiszniewska, J., 2009. An extension of the Svecofennian orogenic province into NE Poland: Evidence from geochemistry and detrital zircon from Paleoproterozoic paragneisses. Precambrian Research, 172: 234-254.

Wiszniewska, J., 2002. Age and the genesis of Fe-Ti-V ores and related rocks in the Suwałki Anorthosite Massif (northeastern Poland) (in Polish with English summary). Biuletyn Państwowego Instytutu Geologicznego, 401: 1-114.

Wiszniewska, J., Sikorska, M., 2005. Minerals-carriers of rareearth elements in carbonatites of the Tajno massif (NE Poland) as evidenced by cathodoluminescence studies (in Polish with English summary). Przegląd Geologiczny, 53: 348-349.

Wiszniewska, J., Claesson, S., Stein, H., Vander Auwera, J., Duchesne, J.C., 2002. The north-eastern Polish anorthosite massifs: petrological, geochemical and isotopic evidence for a crustal derivation. Terra Nova, 14: 451-460.

Woolley, A.R., 1989. The spatial and temporal distribution of carbonatites. In: Carbonatites: Genesis and Evolution (ed. K. Bell): 15-37. Unwin Hyman, London.

Wolley, A.R., Kempe, D.R.C., 1989. Carbonatites: nomenclature, average chemical compositions and element distribution. In: Carbonatites: Genesis and Evolution (ed. K. Bell): 1-14. Unwin Hyman, London.

Zaitsev, A., Bell, K., 1995. Sr and Nd isotope data of apatite, calcite and dolomite as indicators of source and the relationships of phoscorites and carbonatites from the Kovdor massif, Kola Peninsula, Russia. Contributions to Mineralogy and Petrology, 121: 324-335.

Zaitsev, A.N., Wall, F., LE Bas, M.J., 1998. REE-Sr-Ba minerals from the Khibina carbonatites, Kola Peninsula, Russia: their mineralogy, paragenesis and evolution. Mineralogical Magazine, 62: 225-250.

Zaitsev, A.N., Williams, C., Jeffries, T.E., Strekopytov, S., Moutte, J., Ivashchenkova, O.V., Spratt, J., Petrov, S.V., Wall, F., Seltmann, R., Borozdin, A.P., 2014. Rare earth elements in phoscorites and carbonatites of the Devonian Kola Alkaline Province, Russia: examples from Kovdor, Khibina, Vuoriyarvi and Turiy Mys complexes. Ore Geology Reviews, 61: 204-225. 